PAWEŁ STRÓŻYK (Uniwersytet im. Adama Mickiewicza, Poznań) https://orcid.org/0000-0003-1063-3760

\title{
Studia nad wybranymi pieczęciami z herbem miasta Poznania
}

Zarys treści: Trzy prezentowane studia dotyczą wybranych zagadnień związanych z pieczęciami, na których umieszczony został herb Poznania. Są wśród nich pieczęcie poznańskich dominikanek, nowożytne pieczęcie miejskie oraz pieczęć z okresu powstania styczniowego.

\begin{abstract}
The three studies presented here deal with some selected questions connected with seals displaying the coat-of-arms of Poznan. They include seals of Dominican Nuns of Poznan, early modern municipal seals and a seal from the period of the January Uprising.
\end{abstract}

Słowa kluczowe: sfragistyka, pieczęcie dominikanek, pieczęcie miejskie, pieczęcie powstania styczniowego, heraldyka, herb miasta Poznania, Fryderyk Wilhelm Below

Keywords: sphragistics, seals of Dominican Nuns, municipal seals, seals of January Uprising, heraldry, coat-of-arms of the city of Poznań, Friedrich Wilhelm Below

Trzy studia, które tu przedstawiamy, łączy ze sobą wspólna tematyka; wszystkie dotyczą pieczęci i herbów dawnego Poznania. Różne są jednak aspekty, których dotykamy w poszczególnych tekstach - od kwestii heurystycznych, prezentujących nieznane literaturze przedmiotu typy lub warianty pieczęci, poprzez krytyczne (dotyczące zarówno tych już znanych typów, jak i tych nowo opisanych), z ważkimi kwestiami datowania czy autorstwa pieczęci, po interpretacyjne, dotyczące zwłaszcza sposobu prezentacji herbu Poznania i jego obecności w przestrzeni dawnego miasta. Studia nie wyczerpują oczywiście poruszanych tematów i są jedynie przyczynkami w prowadzonych przeze mnie badaniach nad pieczęciami i znakami heraldycznymi Poznania1. Stare przysłowie mówi, że diabeł tkwi w szczegółach. Tę prawdę uświadamiają sobie zwłaszcza ci, którzy zanurzają się w świat dawnych pieczęci. Jakże często bowiem poznawanie ich poszczególnych typów potrafi trwać latami i zależy

${ }^{1}$ P. S tró ży k, Najstarszy herb Poznania, w: Civitas Posnaniensis. Studia z dziejów średniowiecznego Poznania, Poznań 2005, s. 275-293; t e n ż e, Okoliczności wprowadzenia wizerunku murów miejskich do herbu Poznania, w: Mundus hominis - cywilizacja, kultura, natura. Wokół interdyscyplinarności badań historycznych, Wrocław 2006 (Acta Universitatis Wratislaviensis, Historia CLXXV), s. 331-338; t e n ż e, Systematyka średniowiecznych i nowożytnych pieczęci miejskich Poznania. Status causae et controversiae, Roczniki Historyczne 72, 2006, s. 137-152; t e n ż e, Superekslibrisy herbowe z poznańskich ksiąg miejskich. Materiały do historii herbu Poznania, Poznański Rocznik Archiwalno-Historyczny 12-14, 2005-2007, s. 269-275; t e n ż e, Zapomniany wiersz na herb Poznania z XVIII wieku, Roczniki Historyczne 76,2010 , s. 277-282. 
od kolejnych ujawnianych odcisków w trakcie nigdy niekończących się kwerend. A to, co wiemy o poszczególnych typach pieczęci, jest przecież zwykle sumą wiedzy o ich zachowanych egzemplarzach. Potrzeba ciągłego rekapitulowania materiału źródłowego jest więc w obszarze badania pieczęci i herbów sprawą absolutnie fundamentalną. Ustalanie kolejnych faktów źródłowych przekłada się realnie na późniejsze interpretacje i rekonstrukcje historyczne, nie wolno nam zatem zaniedbywać tych drobnych, szczegółowych studiów, choć współczesne tendencje w naukach historycznych są zgoła odmienne. Przypomnijmy więc tu, zwłaszcza niewczesnym krytykom nauk pomocniczych historii, że świat dawnego człowieka można i trzeba też zgłębiać z perspektywy mikrokosmosu źródeł historycznych, a nie tylko syntez, gubiących go zwykle z pola widzenia.

\section{NOWOŻYTNE PIECZECIE POZNAŃSKICH DOMINIKANEK (KATARZYNEK) Z HERBEM MIASTA}

W Archiwum Państwowym w Poznaniu przechowywane jest papierowe pokwitowanie odbioru czynszu w rozliczeniach finansowych prowadzonych pomiędzy poznańskimi dominikankami, zwanymi w ówczesnym mieście katarzynkami, a Janem Czerwieńskim ${ }^{2}$. Ten dość pospolity $\mathrm{w}$ treści dokument, wystawiony i podpisany w 1649 r. przez przeoryszę (Yulianna Szimanowska) i podprzeoryszę (Wiktoria Sultrska) klasztoru św. Katarzyny w Poznaniu ${ }^{3}$, przyciąga szczególną uwagę ze względu na zapowiedzianą i wyciśniętą na nim pieczęć konwentu (,z pieczęci conuentskiey utwierdzeniem"). Ta właśnie pieczęć (wraz z szeregiem innych) będzie przedmiotem naszych uwag (fot. 4).

Ma ona ostroowalny kształt (wysokość $37 \mathrm{~mm}$, szerokość $20 \mathrm{~mm}$ ). W jej polu, obwiedzionym perełkowym obrzeżem, widnieje półpostać św. Katarzyny w koronie i aureoli, trzymająca w prawicy fragment koła o czterech dzwonach i miecz skierowany głownią ku dołowi, przechodzący przez piastę koła. Stan zachowania odcisku nie pozwala z całą pewnością stwierdzić, co święta trzyma w lewej ręce - możliwe, że jest to księga. Przed postacią świętej znajduje się późnogotycka, trójkątna tarcza z dwoma skrzyżowanymi kluczami; nad postacią rozciąga się łuk kotarowy, tworzący rodzaj baldachimu4 .

2 Poznań, Archiwum Państwowe w Poznaniu (dalej cyt.: APP), Akta miasta Poznania I 418, s. 731. Na pokwitowanie natrafiła podczas kwerend archiwalnych mgr Magdalena Kadziszewska-Stróżyk, która zechce w tym miejscu przyjąć podziękowanie za wskazanie mi tego dokumentu.

${ }^{3}$ Obydwie zakonnice odnotował w spisie przeorysz P. S t e fa n i a k, Najstarszy polski klasztor dominikanek klauzurowych i jego mieszkanki, Kronika Miasta Poznania (dalej cyt.: KMP) 2004, nr 3 (Nasi dominikanie), s. 128 (Juliannę Szymanowską pod 1642, a Wiktorię Szołdrską pod 1644 r.). M. B ork o w s k a OSB, Leksykon zakonnic polskich epoki przedrozbiorowej, t. I, Warszawa 2004, s. 112, uwzględniła zarówno Juliannę Szymanowską, jak i Annę Szołdrską (o zakonnym imieniu Wiktoria), jednak bez wskazania ich obecności w przekazie z $1649 \mathrm{r}$.

${ }^{4}$ W kwestii ikonograficznego przedstawiania św. Katarzyny zob. M. P. Kruk, Święta Katarzyna Aleksandryjska i inni święci wschodni w kulcie i sztuce europejskiej u schyłku średniowiecza i na progu czasów nowożytnych, w: Mistrz i Katarzyna. Hans von Kulmbach i jego dzieła dla Krakowa / Der Meister und Katharina. Hans von Kulmbach und seine Werke für Krakau, Kraków 2018, s. 167-192 (tam dalsza literatura przedmiotu). 
U dołu, na banderoli o zawiniętych końcach, znajduje się napis: S[igillum] $\cdot$ S[ancte] - kath|er[i]ne ${ }^{5}$.

Historia konwentu poznańskich katarzynek niestety nie jest dobrze rozpoznana; względnie dobrze zbadane są tylko początki i najstarsze dzieje klasztoru ${ }^{6}$. Niewiele wiemy zwłaszcza o dokumentach zakonnych i pieczęciach używanych przez przełożone oraz konwent. Wobec tego, że nie znamy innych odcisków omawianej pieczęci, rok 1649 musi stanowić dla nas terminus ante quem powstania typariusza, choć był on bez wątpienia znacznie starszy. Kształt użytych liter w legendzie i pewne szczegóły wyobrażenia napieczętnego pozwalają na poczynienie w tej kwestii kilku istotnych spostrzeżeń. Minuskuła gotycka, ale z dwukrotnie użytym majuskulnym $S$, zaczerpniętym z kapitały protorenesansowej, wskazuje na schyłkowy okres stosowania tego pisma w epigrafice (koniec XV i XVI w.) ${ }^{7}$. Także rozetki-dywizory, użyte w napisie napieczętnym, występują w epigrafice monumentalnej w początkach XVI w. ${ }^{8}$ Oczywiście zdajemy sobie sprawę, że tych kilka znaków to więcej niż skromny materiał do porównań, ale tylko takim dysponujemy. Istotny dla datowania pieczęci jest także wykorzystany na niej kształt prostej w rysunku, gotyckiej tarczy, bez jakichkolwiek elementów ozdobnych (języczków, wycięć i wykrojów, profilowania, zaznaczonej osi). Taki kształt, przypominający mandorlę przeciętą w połowie lub nieco poniżej jej wysokości, występował już w XIII w., upowszechnił się w XIV, a wychodził z użycia w pierwszej połowie XV w. (wraz z podobną odmianą o kształcie mandorli przeciętej jednak powyżej jej połowy, co dawało efekt charakterystycznego wybrzuszenia

${ }^{5}$ Ze względu na obecność w inskrypcji trzech kropek uznajemy je za dywizory, a nie (pierwszą i drugą) za znaki brachygraficzne. Zatarta jest na odcisku litera $i$ w imieniu świętej.

6 J. Ł u k a s z e w i c z, Obraz historyczno-statystyczny miasta Poznania w dawniejszych czasach, Poznań 1838, t. II, s. 129-130; T. P r a u s m ü 11 e r, Św. Katarzyna, klasztor dominikanek w Poznaniu 1283-1822, Poznań 1928; Św. Katarzyna. Klasztor dominikanek w Poznaniu 1283-1822. Salezjanie 1926-1928, Poznań 1928; J. N o w a c k i, Dzieje archidiecezji poznańskiej, t. II, Poznań 1964, s. 776; J. W i e s i oł o w s k i, Dominikanie w miastach wielkopolskich w okresie średniowiecza, w: Studia nad historią dominikanów w Polsce 1222-1972, t. I, Warszawa 1975, s. 259-262; t e n ż e, Klasztory średniowiecznego Poznania, w: Początki i rozwój Starego Miasta w Poznaniu w świetle badań archeologicznych i urbanistyczno-architektonicznych, Warszawa-Poznań 1977, s. 405-419; t e n ż e, Dominikanki poznańskie w kręgu mecenatu Przedpełkowiców, KMP 2004, nr 3 (Nasi dominikanie), s. 109-119; P. S t e f a n i a k, Najstarszy polski klasztor, s. 120-130; M. Borkowska OSB, Leksykon, s. 105-121; A. S k or u p i ń s k a, Klasztory żeńskie w średniowiecznej diecezji poznańskiej, w: Historia życia konsekrowanego w archidiecezji poznańskiej, Poznań 2010, s. 36-39. Zob. także opracowania z zakresu historii sztuki: A. D u b o w s k i, Zabytkowe kościoły Poznania, Poznań 1952, s. 72-74; Sz. Skibińs ki, Gotycka architektura kościoła farnego pod wezwaniem Marii Magdaleny w Poznaniu, w: Początki i rozwój Starego Miasta (jak wyżej), s. 421-429; Katalog zabytków sztuki w Polsce, seria nowa, t. VII, cz. II/2, pod red. Z. Kurzawy, A. Kusztelskiego, Warszawa 2002, s. 20-26; Z. K u r z a w a, A. K u s z t e 1 s k i, Historyczne kościoły Poznania. Przewodnik, Poznań 2006; J. K o w a 1 s k i, Gotyk wielkopolski. Architektura sakralna XIII-XVI wieku, Poznań 2010.

${ }^{7}$ B. Tr e 1 i ń s k a, Gotyckie pismo epigraficzne w Polsce, Lublin 1991, s. 60, 64, 105 (ze wskazaniem przykładów z lat 1507, 1509 i 1510 - nr III/290, III/293, III/296). Wprawdzie opracowanie dotyczy tylko liternictwa inskrypcji monumentalnych, ale poczynione w nim obserwacje mogą być dla nas istotnym punktem odniesienia przy próbie datowania pieczęci.

${ }^{8}$ Tamże, s. 142 (z przykładem z 1490 r. - nr III/152). 
boków tarczy) $)^{9}$. Tarcze o takim samym kształcie, jaki widzimy na pieczęci poznańskich dominikanek, spotykamy także na innych pieczęciach, zwłaszcza z XIV w. ${ }^{10}$ O ile tarcza herbowa jest w swej formie jeszcze średniowieczna, o tyle położone na niej klucze, o okrągłych uchwytach, mają już formę charakterystyczną dla czasów nowożytnych. Podobne w kształcie spotykamy na renesansowej oprawie poznańskiej księgi radzieckiej z lat 1546-1548 ${ }^{11}$. Przedstawienie tarczy herbowej i półpostaci nad nią (Matka Boska z Dzieciątkiem, święty patron lub dysponent pieczęci) ma także średniowieczne wzorce, zwłaszcza wśród licznych pieczęci kościelnych z XIV i XV w. ${ }^{12}$, ale brak jakichkolwiek elementów gotyckiej architektury, przy jednoczesnym wykorzystaniu w kompozycji łuku kotarowego, sporadycznie tylko obecnego w architekturze późnego gotyku, wskazuje znów na przełom średniowiecza i czasów nowożytnych. Wydaje się więc, choć określanie daty powstania typariuszy pieczęci na podstawie dużo późniejszych zachowanych odcisków zawsze jest ryzykowne, że tłok powstać musiał w pierwszej połowie XVI w. Biorąc pod uwagę fakt, że pożar

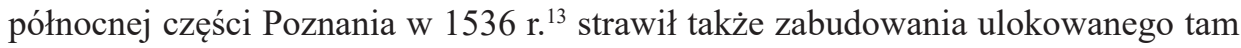
klasztoru, nie można wykluczyć, że powstanie typariusza było konsekwencją tego wydarzenia. Wówczas więc należałoby go datować na drugą połowę lat trzydziestych, ale nie można także wykluczyć, że typariusz powstał nieco wcześniej.

Zauważmy przy tym, że typariusz zdradza pewną nieudolność warsztatową. Widoczna jest przede wszystkim asymetria w zakomponowaniu banderoli, której tylko prawa strona dochodzi do kotarowego łuku rozpościerającego się nad postacią świętej. Miecz nie przechodzi przez piastę dokładnie wzdłuż osi koła, a rozmieszczenie inskrypcji na banderoli - dla patrzącego: od lewego dołu, czyli od środka banderoli, ku jej zawiniętemu końcowi, a następnie od góry po prawej stronie, czyli od drugiego zawinięcia, ku środkowi banderoli - nie jest typowe dla pieczęci o ostroowalnym kształcie. Regularność odstępów pomiędzy literami także pozostawia wiele do życzenia. Mamy zatem do czynienia ze słabszym artystycznie warsztatem, który albo jednocześnie mocno tkwił w stylistyce odchodzącej epoki, albo powielił (z nieznacznymi modyfikacjami) jakąś przedłożoną mu starszą pieczęć klasztorną, co tłumaczyłoby obecność wielu elementów właściwszych raczej dla pieczęci średniowiecznych niż wczesnonowożytnych.

${ }_{9}$ Zob. P. Mro zow s k i, O sztuce i stylizacji heraldycznej w Polsce XIV i XV wieku, Rocznik Polskiego Towarzystwa Heraldycznego, seria nowa, 1, 1993, s. 81-82, tabl. I/8-9 9, $\mathrm{II} / 2, \mathrm{VII} / 3, \mathrm{XI} / 1$.

${ }_{10} \mathrm{~Np}$. M. H l e b i o n e k, Katalog pieczęci przy dokumentach samoistnych w zasobie Archiwum Państwowego w Bydgoszczy, Warszawa 2012, s. 401 nr 230 (1345 r.), s. 496 nr 325 (1360 r.).

${ }^{11}$ Herb miasta Poznania. Publikacja z okazji wystawy zorganizowanej w Starym Ratuszu, opr. J. Olejniczak, Poznań 1967, s. 41, kat. 8, fot. 5.

12 Np. M. G u m o w s k i, Handbuch der polnischen Siegelkunde, Graz 1966, tab. XXXIII nr 334, 339, XXXIV nr 343, 345, XXXV nr 355, XXXVI nr 361, 364, XXXIX nr 391, 395, 397. Zob. także P. P o k o r a, Herby na pieczęciach episkopatu doby jagiellońskiej (do końca XV wieku), w: Pieczęcie herbowe - herby na pieczęciach, Warszawa 2011, s. 150-158.

13 Zob. Die Chronik der Stadtschreiber von Posen, wyd. A. Warschauer, Posen 1888, s. 19-20; Kroniki poznańskich pisarzy miejskich, thum. A. Pawlak, opr. J. Wiesiołowski, Poznań 2004, s. 31-33 (zapiski 43a-c, pod datą: 2 V 1536 r.). 
To, co najciekawsze w ikonografii tej pieczęci, to fakt wyeksponowania w jej polu tarczy z dwoma skrzyżowanymi kluczami. Lokalizacja klasztoru katarzynek i znajomość kontekstu historycznego nie pozostawiają żadnych wątpliwości, że jest to herb Poznania w najstarszej znanej nam jego postaci ${ }^{14}$. Dlaczego jednak herb miasta znalazł się na pieczęci konwentu poznańskich dominikanek? Czy miał on tylko wskazywać na położenie klasztoru w murach miasta i dookreślać jego lokalizację względem innych domów klasztornych, skoro wprost takiej informacji nie przynosiła inskrypcja napieczętna? Czy herb w komunikacie, jaki niosła pieczęć, pełnił funkcję okolicznika miejsca, czy może za jego wyeksponowaniem stały jakieś inne przesłanki? Przypadek jest intrygujący, mamy tu bowiem do czynienia z wykorzystaniem znaku miejskiego przez podmiot znajdujący się wprawdzie „w murach”, ale nienależący do władz miasta ani niebędący agendą miejską, funkcjonujący w odmiennym porządku społeczno-prawnym. Czy było możliwe, aby wspólnota zakonna posługiwała się, ot tak, bez uzasadnionych racji prawnych, znakiem miasta? Waga, jaką przywiązywano do kreowania napisów i wizerunków napieczętnych, zdaje się wykluczać przypadkowość, czy też ewentualną niefrasobliwość ze strony zleceniodawcy i wykonawcy typariusza w zakresie zastosowanych rozwiązań obrazowych. Co zatem oznaczał herb Poznania na pieczęci klasztornej?

Konieczne dla wyjaśnienia tej kwestii będzie odwołanie się do historii poznańskiego konwentu dominikanek, a zwłaszcza sprawy ich patronatu nad miejską farą. Tę kwestię rozpatrzył przed kilku laty Tomasz Jurek ${ }^{15}$, przypominając, że dla powodzenia lokacji miasta Poznania (zwieńczonej dokumentem wystawionym w $1253 \mathrm{r}^{16}$ ) istotna była zgoda biskupa poznańskiego i kapituły katedralnej na odstąpienie książętom wielkopolskim: Przemysłowi I i Bolesławowi Pobożnemu lewobrzeżnych, nadwarciańskich terenów kościelnych. Tytułem rekompensaty ustalono wówczas, że w przypadku erygowania kościoła parafialnego dla nowo lokowanego miasta prawo patronatu tej świątyni pozostanie przy biskupie i kapitule ${ }^{17}$. Gdy w $1263 \mathrm{r}$. erygowano kościół parafialny, a w 1264 r. szpital Świętego Ducha, w roli fundatorów (a więc i patronów) wystąpiły kapituła poznańska (kościoła) i biskup (szpitala), co wynikało z podziału korzyści między tymi podmiotami. Jednak w dokumencie fundacyjnym klasztoru dominikanek z 1282 lub 1283 r. książę Przemysł II nadał

${ }^{14}$ Herbu z pieczęci katarzynek nie sposób łączyć z heraldyką dominikańską, zwłaszcza zaś zgromadzeń żeńskich, zob. W. K o l a k, J. M a r e c k i, Leksykon godeł zakonnych, Łódź 1994, s. 64, 124. Na słabość heraldyki w kręgu żeńskich klasztorów i przyczyny takiego stanu rzeczy zwracał już niegdyś uwagę P. W i s z e w s k i, Herb mało użyteczny. O słabości tradycji heraldycznej wybranych klasztorów żeńskich na Śląsku (XIII - 1. połowa XIX w.), w: Polska heraldyka kościelna. Stan i perspektywy badań, Warszawa 2004, s. 59-77. W kwestii herbu Poznania zob. P. S tr ó ż y k, Najstarszy herb, s. 275-293; t e n ż e, Systematyka, s. 137-152.

15 T. J u r e k, Wokół zagadek najdawniejszych dziejów poznańskiej fary, KMP 2003, nr 3 (Stara i nowa fara), s. 46-62. Streszczamy tu pokrótce poglądy tam wyłożone, opatrując je odsyłaczami do przywołanych dokumentów i cytatów.

${ }^{16}$ Kodeks dyplomatyczny Wielkopolski (dalej cyt.: KDW), t. I [wyd. I. Zakrzewski], Poznań 1877, nr 321; Przywileje miasta Poznania XIII-XVIII wieku, wyd. W. Maisel, Poznań 1994, nr 3. W sprawie etapów lokacji miasta zob. T. J u rek, Przebieg lokacji Poznania, w: Civitas Posnaniensis (jak w przyp. 1), s. 173-191.

${ }^{17}$ KDW I, nr 302; Przywileje, nr 2. 
zakonnicom prawo patronatu kościoła św. Marii Magdaleny (czyli farnego), wraz z przyległym do niego gruntem ${ }^{18}$. W 1296 r., już jako król, Przemysł II wystawił dokument, w którym odnawiając swoje poprzednie nadanie dla zakonnic, stwierdził, że dla materialnego wsparcia klasztoru darowuje im parafię św. Marii Magdaleny, wraz z należącym do niego prawem patronatu ${ }^{19}$. W 1297 r. książę Władysław Łokietek zatwierdził dobra dominikanek, wspominając przy tym, że Przemysł II nadał im kościół św. Marii Magdaleny wraz z gruntem za kościołem, potrzebnym na zbudowanie klasztoru (chodziło o zbudowanie nowego klasztoru, stary bowiem, położony na północno-zachodnim skraju miasta, ucierpiał najprawdopodobniej w wyniku najazdu margrabiów brandenburskich lub księcia głogowskiego ${ }^{20}$. Zagwarantowany więc biskupowi i kapitule poznańskiej podczas lokacji miasta patronat nad farą miejską, uznany został w końcu XIII w. ponownie za prerogatywę władcy i przekazany w ręce dominikanek poznańskich, których klasztor, ówcześnie pod wezwaniem św. Pawła i św. Jana Ewangelisty, ulokowany był w murach miasta. Spór o patronat między dominikankami a biskupem i kapitułą rozstrzygnęli sędziowie wyznaczeni przez króla Kazimierza Wielkiego. W dokumencie z 1337 r. przyznano dominikankom kościół św. Marii Magdaleny, ale posiadany przez zakonnice kościół klasztorny wraz z gruntem oddano biskupowi poznańskiemu ${ }^{21}$. „Mamy tu do czynienia $\mathrm{z}$ iście salomonowym rozstrzygnięciem królewskich komisarzy; uszanowali oni prawa katarzynek, ale faktycznie zablokowali ich realizację, wprowadzając wymóg opuszczenia starego klasztoru. Samym dominikankom najwyraźniej nie zależało już chyba wcale na takim rozwiązaniu i dlatego najpewniej wyrok nie wszedł w życie. W sprawie chodziło $\mathrm{w}$ istocie o prawo patronatu ze wszystkimi wynikającymi z niego korzyściami. Było się zaś o co kłócić, bo poznański kościół parafialny stanowił, jak to określono w pewnej suplice do papieża, »beneficjum znaczne i thuste «"22. Kwestia patronatu jednak ulegała dalszym komplikacjom, w XV w. bowiem władcy postanowili włączyć się do sporu i przejąć patronat nad parafią farną. W 1415 r. wymieniono poznański kościół jako jeden z tych, których patronat należał niegdyś do królów polskich, a które utracili oni w wyniku sprawy św. Stanisława, co stwarzało korzystną podstawę ideową do ubiegania się o jego zwrot ${ }^{23}$. Konflikt nasilił się w 1446 r., po śmierci długoletniego plebana Mikołaja Lantmana ${ }^{24}$. Wśród konkurentów do zwolnionej godności jedni powoływali się na poparcie dziekana (na którego w XV w. przeszły prawa kapituły), inni - dominikanek, jeszcze inni zaś - na poparcie króla, choć de facto trwało wówczas bezkrólewie. Nowy władca - Kazimierz Jagiellończyk - stanowczo uznał prawo patronatu nad świątynią poznańską za prerogatywę królewską, co wobec faktu konieczności odbudowy kościoła po pożarze w 1447 r., łączącej się niewątpliwie z ogromnymi nakładami finansowymi, postawiło go w roli zwycięzcy

\footnotetext{
${ }^{18}$ KDW VI (wyd. A. Gąsiorowski, H. Kowalewicz, Poznań 1982), nr 29.

${ }^{19}$ KDW II ([wyd. I. Zakrzewski], Poznań 1878), nr 743.

${ }^{20}$ KDW II, nr 767, VI, nr 53.

${ }^{21}$ KDW VI, nr 118-119.

${ }^{22}$ T. J u r e k, Wokół zagadek, s. 54.

${ }^{23}$ Bullarium Poloniae, wyd. I. Sułkowska-Kuraś, S. Kuraś, t. III, Romae-Lublini 1988,

${ }^{24}$ T. J u r e k, Wokół zagadek, s. 59-60.
} nr 1468. 
w prowadzonym sporze. „Prawdopodobnie wtedy fara przeszła faktycznie pod patronat królewski, a stan ten uległ legitymizacji poprzez wycofanie się konkurentów. Nie słychać w każdym razie już więcej o roszczeniach kapituły bądź dominikanek, wyraźnie zaś podkreślane bywają coraz częściej patronackie kompetencje króla"25. Odbudowa fary zakończyła się w 1470, a w 1471 r. podniesiono kościół do rangi kolegiaty, erygując przy nim kolegium złożone z dziekana i siedmiu kanoników ${ }^{26}$. W 1555 r. król Zygmunt August odstąpił patronat władzom miasta ${ }^{27}$.

O ile więc wykonanie pieczęci z herbem Poznania (dwa skrzyżowane klucze) miałoby ewentualnie sens ideowy w pierwszej połowie XV w. - zwłaszcza w latach czterdziestych tego stulecia, gdy ta byłaby czytelnym znakiem roszczeń do patronatu nad miejskim kościołem św. Marii Magdaleny - o tyle tak rozumiane treści ideowe na pieczęci z XVI w. muszą zastanawiać. Nie mamy podstaw przypuszczać, aby zakonnice chciały wówczas powrócić do sprawy patronatu, utraconego w XV w. Ponieważ w dokumencie królewskim z 1555 r. nie napomknięto wcale o dominikankach, przyjąć należy, że z ich strony nie pojawiły się żadne roszczenia odwołujące się do ich niegdysiejszych praw patronackich. Zastanawiając się więc nad osobliwymi treściami ideowymi szesnastowiecznej pieczęci klasztornej katarzynek, należy skonstatować, że za wyeksponowaniem na niej herbu miasta nie kryły się zapewne żadne racje natury prawnowłasnościowej, zwłaszcza w kontekście dawnych zmagań wokół patronatu poznańskiej fary.

Wspomnieliśmy już jednak, że obecność wielu średniowiecznych odniesień formalnych nie wyklucza też przypuszczenia, że pieczęć z XVI w. mogła powielać (już bez świadomości dawniejszych odniesień ideowych) jakąś starszą pieczęć klasztorną. Znamy z początku XV w. tylko dwa słabo zachowane odciski starszej pieczęci klasztornej. Pierwszy zachował się w stanie poważnej destrukcji przy dyplomie z 27 X $1404 \mathrm{r}^{28}$ Na pergaminowym pasku wisi obecnie woskowa miska w skórzanej osłonie, zdradzając tylko ostroowalny kształt pieczęci (fot. 1). Trzy osobno zachowane fragmenty $\mathrm{z}$ odwarstwionego od miski woskowego lica pozwalają stwierdzić (fot. 2), że pieczęć wykonano tym samym typariuszem, za pomocą którego odciśnięto pieczęć zachowaną przy dokumencie z 12 X 1412 r. (fot. 3) ${ }^{29}$. Ta pieczęć, choć nieco zatarta i obłamana z prawej strony, pozwala na poczynienie istotnych spostrzeżeń. W polu ostroowalnej pieczęci (o wysokości ok. 50-55 mm i szerokości $30 \mathrm{~mm}$ ), pod gotycką, ostro zamkniętą, trójlistną, maswerkową arkadą, przedstawiono stojącą na konsoli, ukoronowaną postać św. Katarzyny z fragmentem koła w prawicy i mieczem skierowanym ku dołowi w lewicy. Fragmentarycznie zachowany napis, wykonany minuskułą gotycką, głosi: $[\ldots]$ katherine $\cdot$. Biorąc pod

${ }^{25}$ Tamże, s. 56.

${ }^{26}$ P. D e m b i ń s k i, Fundacja i erekcja kolegiaty św. Marii Magdaleny w Poznaniu, KMP 2003, nr 3 (Stara i nowa fara), s. 63-75.

27 Przywileje, nr 137.

28 APP, Dominikanki Poznań, D 5; zob. także KDW VII (wyd. A. Gąsiorowski, R. Walczak, Poznań 1985), nr 530.

29 APP, Dominikanki Poznań, D 6; zob. także KDW VII, nr 698 (wydawcy dostrzegli $\mathrm{w}$ polu pieczęci wyobrażenie kobiety z palmą w prawej i opuszczonym mieczem w lewej; zachowany fragment inskrypcji odczytali jako: conventus + ). 
uwagę ilość miejsca zajętego przez zachowane słowo oraz rozstrzelenie liter, można ostrożnie przyjąć, że inskrypcja miała pierwotnie następującą formę: $[\cdot \mathrm{s} \cdot$ conventus $\cdot \mathrm{s} \cdot]$ katherine $\cdot$

Pieczęć katarzynek wykonana w XVI w. powielała więc ogólny schemat starszej pieczęci klasztornej, znanej nam z początku XV w., wzbogacając go o herb, którego nie było na pieczęci starszego typu (autopsja egzemplarza z 1412 r. wyklucza taką możliwość). Nie mamy wprawdzie koniecznej pewności, czy typariusza, którym je odciśnięto, używano aż do czasów wymiany tłoka w XVI w., nie możemy zatem na tym etapie badań wykluczyć istnienia pomiędzy wymienionymi, jeszcze jednego typu pieczęci, na którym mógłby ewentualnie pojawić się herb z kluczami. Ta kwestia jednak pozostać musi w obszarze spekulacji ${ }^{30}$. Na tym etapie rozpoznania problemu musimy przyjąć, że herb miasta został wprowadzony dopiero na szesnastowieczną pieczęć klasztorną, pełnił swoistą rolę okolicznika miejsca i zastępował środkami obrazowymi to, co już w średniowiecznych dokumentach oddawano rozmaitymi zwrotami: - conventus Posnaniensis; conventus sororum Sancte Katherine domus claustri in Poznania; - monasterii sanctae Catharinae in civitate Posnaniensi; conventus in Posnania; - monasterii et ecclesiae Beate Katherine Poznaniensis; - conventum s. Katherine monasterii in Poznania ${ }^{31}$.

Wprowadzenie herbu miasta na pieczęć klasztorną musiało być, jak sądzę, poprzedzone uzyskaniem zgody ze strony władz municypalnych, a może nawet ich zachętą, w innym razie byłaby to zwykła uzurpacja znaku, którym posługiwało się miasto. Fakt ten, na co należy zwrócić uwagę, zdarzył się w okresie szczególnych relacji klasztoru z miastem. W końcu XV w. nastąpił zwrot w systemie gospodarczym klasztoru, „który od 1491 roku zaczął opierać się na powiązaniach z miastem. W 1491 roku rada miejska potwierdziła przywileje dominikanek, które zaczęły otrzymywać w tym czasie liczne donacje od mieszczan. Mniszki zacieśniły też integrację z Poznaniem, czego owocem były lokaty czynszowe na miejskich nieruchomościach. Mieszczańskie córki coraz częściej przekraczały bramę klasztoru, by nadać nowy ton wspólnocie. Sytuacja ta utrzymywała się do czasu - -, kiedy decydującą rolę w klasztorze przejęły ponownie szlachcianki" ${ }^{\prime 2}$. Nadmieńmy tu, że w pierwszej

${ }^{30}$ Taka pieczęć - jak się wydaje - mogłaby powstać tylko w czasach wzmożonej rywalizacji o patronat nad farą miejską, w obliczu realnej groźby utraty posiadanego przywileju, a więc najpóźniej tuż przed połową XV w.; w innym razie jej sens (program) ideowy byłby niezrozumiały. Przypomnijmy tu, że jeszcze w 1413 r. król Władysław Jagiełło potwierdził katarzynkom patronat fary (KDW VII, nr 714). Sprawę skomplikowało dopiero późniejsze włączenie się w spór strony królewskiej, które miało swoją kulminację tuż przed połową XV w. Wówczas mógłby się ewentualnie zrodzić pomysł nowego typariusza, którego treść wskazywałaby na udział dominikanek w kształtowaniu oblicza miasta i w pewnym zakresie na ich realny wpływ na bieg spraw poznańskich.

${ }^{31}$ KDW VI, nr 217 (1366), 314 (14 VIII 1390), VIII (wyd. A. Gąsiorowski, T. Jasiński, Poznań 1989), nr 1020 (14 III 1415), 853 (30 VII 1419), nr 865 (2 XII 1419); Acta capitulorum nec non iudiciorum ecclesiasticorum selecta, wyd. B. Ulanowski, t. II, Kraków 1901, nr 219 (1447).

${ }^{32}$ P. S t e f a n i a k, Najstarszy polski klasztor, s. 125. Na integrację , dominikanek z organizmem miejskim" w końcu XV i początkach XVI w. wskazywał wcześniej J. W i e s i oło w s k i, Dominikanie w miastach, s. 262-263, wymieniając darowizny dla katarzynek płynące ze strony poznańskich wdów i wpływowych mieszczan. 
połowie XVI w. w klasztorze zakonnicami były m.in. poznańska patrycjuszka Katarzyna Grodzicka i kupiecka córka Łucja Krypianka. Ta pierwsza sięgnęła nawet po godność przeoryszy ${ }^{33}$. Ich krewni piastowali eksponowane godności miejskie, może więc to te zależności zadecydowały o wprowadzeniu herbu miasta w pole pieczęci dominikanek ${ }^{34}$.

Ten stan rzeczy trwał długo. Świadczą o tym trzy kolejne pieczęcie katarzynek, ujawnione w poznańskich archiwaliach. Z 23 III 1747 r. pochodzi papierowy dokument zastawu pary srebrnych lichtarzy, podpisany i opieczętowany ,za konsensem całego zgromadzenia klasztoru S. Katarzyny” przez przeoryszę (,s. Dorota Gorzenska przeorzysza") $)^{35}$. Ostroowalna w kształcie, słabo odciśnięta na papierze i nieco obcięta u samego dołu pieczęć (fot. 5), o wymiarach 34 mm (wysokość domyślna: ok. $40 \mathrm{~mm}$ ) na $20 \mathrm{~mm}$, powtarza ikonograficznie tę znaną nam z 1649 r., z tym tylko, że napis wykonany został kapitałą: S[IGILLUM] · SANCT[E] | KATRIN[E] ${ }^{36}$.

Z 1778 r. pochodzi papierowy kwit poświadczający odbiór przez przeoryszę zgromadzenia pieniędzy należnych katarzynkom („Bogumiła Przanowska przeorzysza konwentu Święty Katarzyny") 37. Opłatkowa, ostroowalna pieczęć o wymiarach ok. $50 \mathrm{~mm}$ na ok. $35 \mathrm{~mm}$ (prostokątny opłatek: $61 \times 43-44 \mathrm{~mm}$ ), słabo wyciśnięta, zachowuje ogólny charakter poprzednich pieczęci katarzynek, ale przynosi zmodyfikowane wyobrażenie napieczętne oraz inne ułożenie napisu (fot. 7). W polu pieczęci widnieje wprawdzie półpostać świętej ponad tarczą herbową, ale inaczej trzyma ona swoje atrybuty - miecz skierowany ku dołowi w prawicy, koło zaś (z widocznymi czterema dzwonami) w lewicy. Kompozycyjnie, atrybuty świętej otaczają tarczę z obydwu stron. Inny kształt ma także symetryczna tarcza (o renesansowym, co ciekawe,

${ }^{33}$ Zob. J. Wi e s i ołow s ki, Dominikanie w miastach, s. 259, 262; P. S te fan iak, Najstarszy polski klasztor, s. 125-126 (tam wymienione także inne zakonnice mieszczańskiego pochodzenia); M. B o r k o w s k a OSB, Leksykon, s. 108-109. Katarzyna i Łucja wymienione zostały w dokumentach z lat 1515 (APP, Dominikanki Poznań, D 11: Katherina Grodziczska, Lucia) oraz 1524 (tamże 46, s. 2-4: Lucia et Catharina). Katarzynę jako przeoryszę wspomina dokument z 1557 r. (tamże 56, s. 183: Catherina Grodziczka priorissa).

34 Jan Grodzicki był ławnikiem w 1. 1491, 1492, 1493 i 1503, rajcą 1495, 1501, 1504, $1505,1506,1507,1508,1509,1510$, a burmistrzem 1498, 1499 i (jako kolejny rajca siedzący) w 1507; jego syn, także Jan Grodzicki, był ławnikiem w 1. 1521, 1522, 1524, 1525, rajcą 1530 (i szafarzem), 1531, 1532, 1533 (i szafarzem), a burmistrzem 1535, 1536, 1537, 1539 (dwukrotnie), 1540, 1543, 1545, 1553. Brat tego ostatniego Jakub był ławnikiem w 1. 1537, 1539 (dwukrotnie) i 1540. Ojciec Łucji, Jan Krypa, był ławnikiem w 1. 1521, 1522, 1523, a rajcą 1524, 1525 i 1528 - Władze miasta Poznania, t. I, opr. J. Wiesiołowski, Z. Wojciechowska, Poznań 2003, s. 61-110; zob. także M. G r y c z, Grodzicki Jan, w: Wielkopolski słownik biograficzny, Warszawa-Poznań 1981, s. 230-231.

35 APP, Akta miasta Poznania I 1873, s. 457a (na pieczęć natrafiła w trakcie kwerend mgr Magdalena Kadziszewska-Stróżyk). Przeoryszę odnotowali P. S t e f a n i a k, Najstarszy polski klasztor, s. 128, oraz M. B or k o w s k a OSB, Leksykon, s. 118.

${ }^{36}$ Pierwotna obecność w napisie końcowego $E$ w słowie KATRIN[E], nie jest pewna, biorąc pod uwagę niewielką ilość miejsca na jej wstawienie, ale może litera ta była nadpisana albo tworzyła ligaturę z $N$. Tylko znajomość innego, lepiej zachowanego odcisku pozwoli nam zweryfikować ten szczegół.

37 APP, Dominikanki Poznań 39, s. 1. Wśród przeorysz Bogumiłę Przanowską uwzględnił P. S te faniak, Najstarszy polski klasztor, s. 128; zob. też M. B ork ow s k a OSB, Leksykon, s. 120. 
kształcie), na której widoczne są dwa skrzyżowane klucze o sercowych uchwytach. Stan odcisku nie pozwala stwierdzić, jak opracowana została górna część wyobrażenia napieczętnego. Fragmentarycznie tylko czytelny, majuskulny napis, biegnący tym razem zgodnie z ruchem wskazówek zegara, głosi: [...]TARIN[E ·] POSNANI[...].

Znamy jeszcze jedno sigillum konwentu katarzynek (,przy położeniu konwenckiey pieczęci"), tym razem okrągłe, wyciśnięte na papierowym dokumencie z 1762 r., z podpisem przeoryszy (,Agniszka Baranoska przeorzysza konwentu poznanskiego Katarzyny z OSD") 38. Pieczęć o średnicy $40 \mathrm{~mm}$ jest niemal nieczytelna (fot. 6). $\mathrm{W}$ jej polu majaczy półpostać (zapewne św. Katarzyny) trzymająca w prawej ręce koło (bardzo słabo widoczny jest jego fragment), a w lewej miecz, jak sądzić należy z kształtu zatartego obiektu. W odpowiednim oświetleniu dostrzec można zarys jednej z bocznych krawędzi niemal niewidocznej tarczy herbowej (o renesansowym kształcie) oraz jeden bardzo słabo widoczny uchwyt od klucza, co świadczy o tym, że przed półpostacią widniała tarcza z dwoma - jak możemy się domyślać per analogiam - skrzyżowanymi kluczami. Z liter niemal nieczytelnego napisu, przy odpowiednim oświetleniu bocznym, można dostrzec - po prawej, postępując od góry pieczęci, zgodnie z ruchem wskazówek zegara, następujące znaki: GILLVM : · : CONV, po lewej zaś tylko litery: IN. To pozwala ostrożnie przyjąć, że legenda napieczętna głosiła: [SI]GILLVM : · : CONV[ENTVS · S · KATAR]IN[E]. Pieczęć z 1762 r. (podobnie jak ta z 1778 r.), zachowując schemat ikonograficzny pieczęci poznańskiego klasztoru, w inny kompozycyjnie sposób ukazuje atrybuty należne św. Katarzynie (miecz i koło), herb zaś prezentuje w dekoracyjniejszej tarczy. Jej inny kształt (okrągły) skłania do postawienia pytania, czy nie była to aby pieczęć mniejsza, używana równolegle z pieczęcią ostroowalną, ale na tym etapie badań musimy to pytanie pozostawić bez odpowiedzi.

Przypadek wprowadzenia w XVI w. w pole pieczęci dominikanek herbu Poznania jest tym ciekawszy, że bezprecedensowy także z perspektywy heraldyki miejskiej. Funkcje herbu miejskiego i kwestię jego nośników w okresie staropolskim szeroko omówił niegdyś Marek Adamczewski ${ }^{39}$, wskazane jednak przez niego przykłady dotyczą tylko używania herbów przez władze miejskie lub związane z nimi podmioty, np. cechy rzemieślnicze. W obszarze kościelnym odnotował on wyłącznie przypadki pojawiania się herbów miejskich na srebrach (relikwiarze, monstrancje, pacyfikały, wota) oraz dzwonach przeznaczonych dla kościołów, a fundowanych przez władze miejskie lub konkretnych mieszczan, albo na pieczęciach lub w wystroju kościołów parafialnych ${ }^{40}$. Przypadkiem dla nas ciekawym jest przywołana przez M. Adamczewskiego pieczęć poznańskiego kościoła farnego z przedstawieniem jego patronki - św. Marii Magdaleny, stojącej na dwóch skrzyżowanych kluczach (fot. 8$)^{41}$.

${ }^{38}$ APP, Dominikanki Poznań 48, s. 64 (cały dokument: s. 62-64). Agnieszkę Baranowską odnotowali P. S t e f a n i a k, Najstarszy polski klasztor, s. 128, oraz M. B o r k o w s k a OSB, Leksykon, s. 119.

${ }_{39}$ M. A d a m c zew ski, Funkcje użytkowe herbu miejskiego do końca XVIII wieku, Rocznik Polskiego Towarzystwa Heraldycznego, seria nowa 4, 1999, s. 67-99.

40 Tamże, s. 84-85.

${ }^{41}$ Tamże, s. 83 (z przywołaniem odcisku z 1798 r. - APP, Cechy miasta Poznania 449, k. 42). 
Ale i tu nie wychodzimy poza krąg podmiotów zależnych od władz miejskich, do których - przypomnijmy - należało od 1555 r. prawo patronatu poznańskiej fary miejskiej ${ }^{42}$. Obecność na pieczęci tego kościoła znaku miejskiego ma więc swoje realne uzasadnienie, podobnie jak odnotowana w przekazach obecność miejskiego herbu we wnętrzu tej świątyni. Przypadek pieczęci klasztornej poznańskich katarzynek jest jednak innego rodzaju, choć wizualnie wydawać by się mogło, że ma taki sam charakter, jak pieczęć farna. Klasztor katarzynek w Poznaniu w żaden przecież sposób nie podlegał bezpośrednio władzom miasta, pomijając oczywiście fakt, że znajdował się na terenie przez te władze zarządzanym. Występowanie herbu miejskiego w roli okolicznika miejsca znajduje analogie dopiero w pieczęciach sądów funkcjonujących w miastach Rzeczypospolitej w okresie zmian ustanowionych przez Sejm Wielki ${ }^{43}$. Sądy pierwszej instancji (wyrokujące jako miejskie) posługiwały się - zgodnie z ustawą - pieczęciami z wyobrażeniami herbów miast, sądy zaś apelacyjne i kryminalne (wyrokujące w imieniu królewskim) posługiwały się pieczęciami z herbami państwowymi (Orzeł Biały lub Pogoń), pod którymi umieszczany był herb miasta - siedziby sądu. Te ostatnie herby miały właśnie analogiczne znaczenie wskazywały miejsce, w którym lokował się podmiot będący właścicielem pieczęci (siedziba sądu). Są to jednak przypadki znacznie późniejsze.

Przyjmując jednak, że tarcza z herbem Poznania trafiła na pieczęć katarzynek w pierwszej połowie XVI w., w okresie wzmożonych związków gospodarczych i społecznych (także rodzinnych) klasztoru z miastem, można postrzegać wymowę herbu także jako widomy znak zacieśnienia tych właśnie związków. Klasztor dominikanek stał się wówczas „miejski”, nie tylko z racji swojego położenia, ale także ze względu na gospodarczą, społeczną, a i religijną rolę spełnianą na rzecz społeczności miejskiej. Katarzynki stały się więc wówczas integralnym elementem tkanki mieszczańskiego żywiołu. Na koniec zauważmy, że obecność na pieczęci poznańskich dominikanek herbu z dwoma skrzyżowanymi kluczami nie tylko jest świadectwem rozprzestrzeniania się znaku w przestrzeni publicznej miasta, lecz także potwierdza nam wygląd najstarszego herbu, którym posługiwało się miasto ${ }^{44}$.

\section{NOWOŻYTNA PIECZEĆC MIEJSKA POZNANIA TYPU III I JEJ WARIANTY}

Podsumowując niegdyś badania nad średniowiecznymi i nowożytnymi pieczęciami miejskimi Poznania, wyraziłem nadzieję, że w toku dalszych kwerend archiwalnych będziemy mogli naszą wiedzę o tych pieczęciach znacząco uzupełniać i korygować ${ }^{45}$. Nadzieja ta bynajmniej nie okazała się płonna, kwerendy bowiem przynoszą wciąż nowe ustalenia. W niniejszym przyczynku przedstawimy istotne uzupełnienia dotyczące jednej z publikowanych już pieczęci radzieckich. Pieczęć ta, określona przeze mnie jako typ III, została wcześniej opisana przez Mariana Gumowskiego, a za nim

42 Zob. wyżej, przyp. 27.

${ }^{43}$ M. B o g u c k a, H. S a m s o n o w i c z, Dzieje miast i mieszczaństwa w Polsce przedrozbiorowej, Wrocław 1986, s. 584-586; M. A d a m c z e w s k i, Funkcje użytkowe herbu, s. 76.

${ }^{44}$ P. S t ró ż y k, Najstarszy herb Poznania.

45 Te n że, Systematyka, s. 137-152. 
przez Mariana Haisiga ${ }^{46}$. Według tych badaczy była to jedna $\mathrm{z}$ trzech mniejszych pieczęci miejskich Poznania wprowadzonych do użytku kancelaryjnego w XVI w., a wykorzystywanych także w XVII i XVIII w.

W polu pieczęci (o średnicy $33 \mathrm{~mm}$ i legendzie: S · CIVITATIS POSNANIENSIS) umieszczone były - zdaniem M. Gumowskiego i M. Haisiga - dwa skrzyżowane klucze, nad nimi tarcza herbowa z orłem, a powyżej popiersie anioła. Znajomość innych odcisków pieczęci typu III pozwoliła jednak na wprowadzenie już w $2006 \mathrm{r}$. dość istotnej korekty do tych opisów. Otóż nie tylko orła, lecz także dwa skrzyżowane pod nim klucze twórca tłoka umieścił w polu tarczy herbowej. Korekta w opisie możliwa była dzięki ujawnieniu odcisków, lepiej zachowanych od tych, którymi dysponowali przywołani badacze ${ }^{47}$. W przypadku bowiem, gdy typariusz używany był w kancelarii przede wszystkim do pieczętowania dokumentów papierowych, w wosku przez papier (a z takimi właśnie przypadkami mamy tu do czynienia), dysponujemy zwykle niezbyt wyraźnymi odciskami, co wpływa na jakość opisu pieczęci. Przy zatartych odciskach łatwo o istotne opustki lub omyłki przy opisywaniu widniejących na pieczęci elementów obrazowych lub legendy. Precyzyjny opis niestarannie i zwykle dość płytko wyciśniętych pieczęci przez papier bywa niekiedy - o czym należy pamiętać - nie lada wyzwaniem. Odnotujmy też, że kilku badaczy podejmujących kwestie sfragistyki i heraldyki miejskiej Poznania w ogóle nie wzmiankowało interesującego nas typu pieczęci ${ }^{48}$.

Kwerendy prowadzone w ostatnich latach w Archiwum Państwowym w Poznaniu ujawniły kolejne odciski pieczęci typu III, wśród których są także odciski bardzo wyraźnie wyciśnięte i dobrze zachowane ${ }^{49}$. To pozwala na dokonanie kilku dalszych spostrzeżeń, istotnie wzbogacających naszą wiedzę o tej pieczęci, a także o funkcjonowaniu pieczęci dawnego Poznania w ogóle. Kilka ujawnionych i prezentowanych tu egzemplarzy, stosunkowo dobrze wyciśniętych i zachowanych, nie pozostawia wątpliwości co do tego, że na piersi orła umieszczona była tarcza z rodowym herbem króla, czego nie można było stwierdzić na podstawie dotąd znanych odcisków. Nowo odkryte odciski przynoszą w dodatku wizerunki dwóch różnych herbów królewskich. Na jednym (fot. 9) wyraźnie widoczny jest herb Korybut króla Michała (1669-1673) ${ }^{50}$,

${ }^{46}$ M. G u m o w s k i, Pieczęcie i herby miast wielkopolskich, Poznań 1932, s. 263-264 (z odesłaniem do odcisków z lat 1631, 1632 i 1729, pochodzących z Archiwum Poznańskiego, ale bez podania sygnatur); M. H a is ig, Pieczęć i herb miasta Poznania, w: Dziesięć wieków Poznania, t. I, Poznań-Warszawa 1956, s. 324 (bez odesłania do konkretnych dokumentów).

${ }^{47}$ P. S tró ży k, Najstarszy herb, s. 283, przyp. 47, tabl. III/4; t e n ż e, Systematyka, s. 141 , przyp. 23 , tabl. I/3.

${ }^{48}$ Herb miasta Poznania (J. O lej n i c z a k); I. R a d t k e, Kancelaria miasta Poznania do roku 1570, Warszawa 1967; t e j ż e, Kancelaria miasta Poznania w latach 1570-1793, w: Historia prawa, historia kultury. Liber memorialis Vitoldo Maisel dedicatus, Poznań 1994, s. 99-111; M. A d a m c zew s k i, Heraldyka miast wielkopolskich do końca XVIII wieku, Warszawa 2000.

49 Na pieczęcie w aktach miasta Poznania natrafiła w trakcie kwerend w 2013 r. mgr Magdalena Kadziszewska-Stróżyk.

50 APP, Akta miasta Poznania I 2115, s. 9 (fot. 9); zob. także inne, znacznie mniej wyraźne odciski z herbem Korybut: tamże I 2160, s. 28; I 2161, s. 7; I 2162, s. 28, 63, 67. 
na innych (fot. 10 i 11) - herb Janina króla Jana III (1673-1696) ${ }^{51}$. Wobec tych samych rozmiarów odcisków, identyczności kształtu i położenia wszelkich dających się porównać elementów legendy oraz wyobrażenia napieczętnego, należy przyjąć, że użytkowany typariusz został przerobiony $\mathrm{w}$ tym niewielkim, acz znaczącym szczególe. Zachowany egzemplarz z herbem Korybut wyraźnie ujawnia także inny szczegół ikonograficzny - niewielką, uskrzydloną, anielską głowę podtrzymującą tarczę herbową z orłem i kluczami, zwykle niedociśniętą lub zatartą na innych, wcześniej znanych egzemplarzach pieczęci. Autopsja wybranych odcisków pozwala też stwierdzić ponad wszelką wątpliwość, że przedstawiony orzeł jest ukoronowany, a zatem, że jest to Orzeł Biały, a tarcza herbowa - co istotne - jest dwudzielna w pas (Orzeł Biały w górnym, skrzyżowane klucze w dolnym polu). Wyraźnie widoczna linia podziału tarczy na jednym z ujawnionych odcisków (fot. 11, 14), na wielu innych w ogóle nie jest zauważalna lub nie daje pewności, czy jest to zamierzony przez twórcę element wyobrażenia. Wcięte pobocznice tarczy flankowane są przez dwie zwierzęce głowy, najprawdopodobniej lwie. Górna krawędź tarczy przybrała liściastą formę, dolne zaś boki tarczy podkreślono wyraźnym perełkowaniem. Pole tarczy najprawdopodobniej wypełniono damaskinażem, choć kwestii tej nie sposób ostatecznie przesądzić.

Musimy więc przyjąć istnienie wariantów pieczęci typu III. Pytanie tylko: ilu? Rozpoznaliśmy dwa: $z$ herbem Korybut oraz z herbem Janina. M. Gumowski wskazał jednak na znane sobie egzemplarze pieczęci z 1631 i 1632 r. z Archiwum Poznańskiego, co sugeruje istnienie jeszcze jednego, starszego wariantu. Odcisku z $1631 \mathrm{r}$. nie udało się dotąd odszukać, ten zaś z $1632 \mathrm{r}$. był już przez nas - o czym wspomnieliśmy - reprodukowany ${ }^{52}$. Pieczęć ta jest mocno zatarta i nie pozwala stwierdzić, jaki znak i w jakiej formie (herb/godło herbowe) widnieje na piersi Orła, i czy w ogóle był tam obecny. Przede wszystkim jednak data nie jest miarodajna, ów dokument jest bowiem ekstraktem z akt radzieckich, sporządzonym, jak zwykle, bez podania daty tej czynności przez notariusza Jana Czeszkowica. Ten zaś notowany jest jako pisarz miejski dopiero w drugiej połowie XVII w. (w dokumentach uchwytny od $1658 \mathrm{r}$. $)^{53}$. Zachowany odpis dokumentu z $1632 \mathrm{r}$. sporządzono i opieczętowano więc kilkadziesiąt lat później. Późniejszy jest zatem też egzemplarz uwierzytelniającej go pieczęci, choć nie przesądza to o czasie wykonania samego typariusza.

Na jednym z osiemnastowiecznych odcisków pieczęci typu III dostrzegalna jest w pasie legendy napieczętnej - rozdzielona półpostacią anioła, podtrzymującego tarczę herbową - data: 16-71 (fot. 13), wykonana drobnymi cyframi o wysokości ok. $1 \mathrm{~mm}^{54}$. Przyjąć możemy, że odnosi się ona albo do czasu wykonania typariusza,

51 APP, Akta miasta Poznania I 1494, s. 37 (fot. 10); I 2161, s. 77; I 2162, s. 171 (fot. 11); I 2134 , s. 34.

${ }^{52}$ P. S t r ó ż y k, Najstarszy herb, tabl. III/4.

53 Przed nim urząd ten sprawowali: Maciej Widbor od 1625 r. do początku lat trzydziestych, Jan Karol Dachnowski 1632-1639 oraz Stefan Turski od 1641 r., zob. Die Chronik der Stadtschreiber, s. XXXII-XXXIV; Kronika poznańskich pisarzy miejskich, s. 15-16.

${ }^{54}$ APP, Akta miasta Poznania, sygn.: I 1494, s. 37; o znaczeniu i wymowie dat na pieczęciach miejskich zob. M. H a i s i g, Studia nad legendą pieczęci miejskiej, Wrocław 1953, s. 69-73. 
albo jego przerobienia (co jednak mniej przekonujące) ${ }^{55}$. Przesłanek dodatkowych dla ustalenia czasu powstania pieczęci typu III może nam dostarczyć odpowiedź na pytanie: czy pieczęć tego typu zastąpiła pieczęć typu II (fot. 12) - wówczas ostatni uchwytny odcisk typu II stanowiłby terminus post quem wprowadzenia typu III, czy też może przez pewien czas obydwa typy używane były jednocześnie, jak dotychczas przyjmowano w literaturze przedmiotu? Zachowane źródła zdają się wskazywać na to, że pieczęć typu III zastąpiła w kancelarii miejskiej Poznania pieczęć typu II. Odcisk pieczęci typu II spotykamy bowiem najpóźniej przy dokumencie z 1670, wciągniętym do ksiąg wójtowskich w początkach sierpnia $1671 \mathrm{r}^{56}$ Późniejszych odcisków nie potrafimy wskazać na tym etapie badań. Jednocześnie pieczęcie typu III (z herbem Korybut na piersi Orła) - na tyle dobrze wyciśnięte, abyśmy zachowali pewność, że mamy do czynienia z tym właśnie wariantem - są źródłowo uchwytne (najwcześniej) od 1672 r. (ekstrakty z akt radzieckich z datami: 1672, 1674, 1677) ${ }^{57}$. Z uwagi na obecność herbu Korybut pieczęć w tym właśnie wariancie nie mogła pojawić się wcześniej niż po 19 VI 1669 r. (wybór „Piasta” na króla), ani później niż koniec 1673 r. (śmierć króla Michała I), jednakże ostatni znany nam przypadek użycia pieczęci typu II, a także data umieszczona na typariuszu pozwalają nam przyjąć, że to w $1671 \mathrm{r}$. zaprzestano używania pieczęci typu II, wprowadzając na jej miejsce do obiegu kancelaryjnego pieczęć typu III w wariancie z Korybutem; pozwala to także wykluczyć istnienie jakiegoś starszego wariantu pieczęci typu III ${ }^{58}$. Tym samym pieczęć z Korybutem możemy określić jako wariant A typu III.

Nie znamy okoliczności powstania nowego typariusza (typ III A), ale intrygujący jest pewien szczegół związany z obsadą władz miasta Poznania. Otóż na przełomie lat sześćdziesiątych i siedemdziesiątych XVII w., w kadencjach 1668-1669, 16691670, 1671-1672, 1672-1673, 1673-1674, 1674-1675, prowizorem pieczęci był kupiec i rajca miejski Grzegorz Gościejewicz, ale - raz jeden w ciągu siedmiu lat - w kadencji 1670-1671 został nim Wojciech Budzyniewicz, rajca miejski i wzięty złotnik (kupiec Grzegorz Gościejewicz został wówczas obrany wójtem) ${ }^{59}$. Czy zatem

${ }^{55}$ Nie możemy jednak wykluczyć, że datę 1671 wprowadzono (dodano lub zmieniono) w pole istniejącej już matrycy pieczęci. Wprawdzie, jak wspominaliśmy, pieczęć datowaną przez M. Gumowskiego na 1632 r. wyciśnięto później, ale mogło się to stać już ok. 1658 r. Poza tym jest jeszcze nieodnaleziony egzemplarz z 1631 r., choć i do jego datowania - nota bene - mogą odnosić się podobne zastrzeżenia, jakie zgłosiliśmy wobec pieczęci z 1632 r. Mógł więc już przed $1671 \mathrm{r}$. istnieć typariusz, który w tym właśnie roku (1671) poddano przeróbkom.

${ }_{56}$ APP, Akta miasta Poznania I 432, k. 453v (wpis z 3 VIII 1671); P. S tró ż y k, Systematyka, tabl. I/2 (z datą 1670).

57 APP, Akta miasta Poznania I 2160, s. 28 (ekstrakt z akt radzieckich, z datą 1677); I 2161, s. 7 (ekstrakt z akt radzieckich z datą 1672); I 2162, s. 63 (ekstrakt z akt radzieckich $\mathrm{z}$ datą 1674), 67 (ekstrakt $\mathrm{z}$ akt radzieckich $\mathrm{z}$ datą 1674). Osobnym przypadkiem pozostaje uwierzytelniony pieczęcią z Korybutem ekstrakt z datą 1646 (I 2162, s. 28), odnoszącą się do czynności prawnej, a nie do momentu wystawienia poświadczenia (zapewne także z lat siedemdziesiątych XVII w.).

${ }_{58} \mathrm{Z}$ dotychczasowych ustaleń wynikało, że obydwa typy - przynajmniej przez pewien czas, od lat trzydziestych do końca lat sześćdziesiątych XVII wieku - współwystępowały ze sobą w kancelarii miejskiej, zob. P. S t r ó ż y k, Systematyka, s. 139-141, tam przegląd stanowisk badawczych i odnośna literatura przedmiotu.

${ }^{59}$ Władze miasta Poznania, t. I, s. 248-255. 
wykonania nowego typariusza nie należałoby łączyć właśnie z osobą złotnika Wojciecha Budzyniewicza ${ }^{60}$ i końcowym okresem sprawowanej przez niego, od 21 IX 1670 do 20 IX 1671 r., godności prowizora pieczęci? Na tym etapie badań nie możemy oczywiście przesądzić tej kwestii, ale sugerowany trop wydaje się bardzo intrygujący $^{61}$. Zauważmy na marginesie, że pewne stylistyczne podobieństwa z pieczęcią miasta Poznania (typ III) zdradza też nieco wcześniejsza pieczęć cechu krawców Chwaliszewa z 1662 r. ${ }^{62}$ Może zatem i ten cechowy typariusz wyszedł spod ręki lub z warsztatu Wojciecha Budzyniewicza.

Po śmierci króla Michała typariusz przerobiono, zmieniając herb królewski umieszczony na piersi Orła Białego, z Korybuta na Janinę (typ III B). Pytanie: kiedy do tego doszło? Terminus post quem stanowi moment obrania na króla Jana Sobieskiego (1673), ale odcisk pieczęci z Korybutem umieszczony pod ekstraktem z datą 1677, a zwłaszcza odcisk wyciśnięty pod ekstraktem z datą 1687, wskazują jednoznacznie, że do przerobienia tłoka nie doszło w nieodległym czasie po zmianie na tronie Rzeczypospolitej, jak można byłoby się spodziewać, ale najwcześniej dopiero w kilkanaście lat później (1687). Widocznie władzom miasta ta heraldyczna nieścisłość na pieczęci miejskiej zupełnie nie przeszkadzała. Możliwe wobec tego, że do przerytowania typariusza doszło dopiero przy okazji zmiany ustroju miasta w końcu panowania Jana III, ale kwestię tę należy dalej badać. „W 1693 roku król wprowadził w Poznaniu 12 rajców dożywotnich, niespodziewanie realizując późnośredniowieczne marzenia patrycjuszy miejskich. Czterech kandydatów na burmistrzów wyłącznie spośród dożywotnich rajców zgłaszali staroście aktualny wójt, arcyławnik z pozostałymi ławnikami oraz nowo powołane kolegium 20 mężów, czyli vigintivirów. Wybór osób na stanowiska burmistrzów należał do starosty generalnego. W razie śmierci dożywotniego rajcy jego następcę wybierali sami członkowie rady, wyłącznie spośród dożywotnich ławników. Rajcy wybierali też ze swego grona wójta"63.

Po śmierci króla Jana III pieczęć była nadal wykorzystywana w kancelarii radzieckiej, o czym świadczą licznie zachowane odciski w aktach miejskich, ale nic nie wskazuje na to, aby ponownie została przerobiona i tworzyła następny wariant. Znakomicie zachowane egzemplarze z XVIII w. ${ }^{64}$ nie pozostawiają żadnych wątpliwości co do tego, że przez kolejnych kilkadziesiąt lat, w czasach saskich, nadal

${ }^{60}$ A. W a s i 1 k o w s k a, Budzyniewicz Wojciech, w: Wielkopolski słownik biograficzny, Warszawa-Poznań 1981, s. 85; Spis złotników poznańskich od XV do XVIII wieku wg Tadeusza Nożyńskiego. Materiały do dziejów złotnictwa poznańskiego, opr. Z. Dolczewski, Kronika Miasta Poznania 2000, nr 1 (Złotnicy), s. 10; A. W a s i 1 k o w s k a, O złotnikach wyszkolonych w Krakowie, a działających w Poznaniu w XVII wieku, tamże, s. 119-121.

${ }^{61}$ Znamy inne, źródłowo udokumentowane przypadki wykonywania pieczęci dla władz miejskich Poznania przez miejscowych złotników, zob. T. N o ż y ń s k i, Złotnictwo poznańskie do końca XVIII w., Studia i Materiały do Dziejów Wielkopolski i Pomorza 6, 1960, z. 1 (11), s. 5-63; Herb miasta Poznania (J. O le j n i c z a k), s. 17.

${ }^{62}$ W APP, Tłoki, sygn. T X, 133, zachował się typariusz tej pieczęci - Zbiór tłoków i stempli pieczętnych w zasobie Archiwum Państwowego w Poznaniu, red. P. Pokora, Poznań 2015, nr 607 (tam dalsza literatura przedmiotu).

${ }_{63}^{6}$ J. W i e s i o ł o w s k i, Wstęp, w: Władze miasta Poznania, t. I, s. VI.

${ }^{64}$ APP, Akta miasta Poznania I 1494, s. 37 (fot. 10); I 2134, s. 34. Zob. też P. S t r ó ż y k, Systematyka, s. 141. 
funkcjonował niezmieniony wariant III B (z Janiną), co w ogóle nie przeszkadzało ówczesnym władzom miejskim.

W zakresie treści ideowych pieczęć typu III była de facto kontynuacją typu II. Legenda napieczętna, określająca właściciela typariusza, została powtórzona literalnie. Powtórzony został także ogólny schemat wyobrażenia napieczętnego - tarcza dwudzielna w pas, z Orłem Białym w górnym polu i kluczami w polu dolnym, podtrzymywana przez półpostać uskrzydlonego anioła. Wyobrażenie na pieczęci typu III zostało jednak wzbogacone pewnymi szczegółami - niewielką tarczą z herbem królewskim na piersi Orła (z Korybutem lub Janiną), anielską, uskrzydloną główką u dołu tarczy oraz lwimi głowami okalającymi boki tarczy. Różnice w kształcie tarczy i kluczy wynikają - rzecz jasna - ze stylistyki, innej dla okresu renesansu (typ II), innej dla baroku (typ III). Tarcza herbowa na piersi Orła była powszechnym i charakterystycznym elementem dla wyobrażeń heraldycznych z czasów królów elekcyjnych, których herby łączono w ten sposób z Orłem Białym ${ }^{65}$. Istotną i znaczącą kwestią, na którą koniecznie należy zwrócić uwagę, jest poziomy podział tarczy w obydwu typach pieczęci (II i III), co można było zaobserwować dopiero po odszukaniu odpowiednio dobrze zachowanych odcisków (fot. 11-12, 14-15) ${ }^{66}$. Wbrew temu, co przyjmowano w literaturze ${ }^{67}$, Orzeł i klucze umieszczone są w dwu osobnych polach. Na dwupolowej tarczy herbowej przedstawiono zatem dwa osobne herby: herb Orzeł Biały oraz herb ze skrzyżowanymi kluczami, nie zaś pojedynczy herb, którego godło składa się z dwu połączonych elementów (Orła i kluczy). Na pieczęciach ukazano więc herb złożony, a nie herb łączony ${ }^{68}$, co pozwala nam na doprecyzowanie poglądów na heraldykę Poznania w XVI i XVII w. Ten i inne szczegóły wyobrażenia napieczętnego uświadamiają też, jak ważne dla pełnego rozpoznania zagadnień heraldycznych i sfragistycznych mogą okazać się kolejne ujawniane odciski znanego skądinąd typu pieczęci.

Na tym więc etapie badań przyjmujemy, że szesnastowieczna pieczęć miasta Poznania (typ II), używana była do $1671 \mathrm{r}$. Zastąpiła ją wówczas pieczęć typu III (wariant $\mathrm{A}-\mathrm{z}$ herbem Korybut na piersi Orła Białego). Obydwa typy (II, III) nie funkcjonowały zatem jednocześnie w kancelarii miejskiej, jak dotąd przyjmowano. Typariusz pieczęci typu III został przerytowany najwcześniej w 1687 r., tworząc jej wariant B. Zmiana polegała na wprowadzeniu w miejsce Korybuta, herbu króla Michała, Janiny Sobieskich. Taką pieczęcią (typ III B), bez wprowadzenia jakichkolwiek dalszych przeróbek, posługiwano się w poznańskiej kancelarii jeszcze po połowie XVIII w. ${ }^{69}$

${ }^{65}$ A. Z n a mi e row s ki, Elementy herbu polskiego 1295-1995, w: Orzeł Biały - herb państwa polskiego, Warszawa 1996, s. 91-92; A. J a w o r s k a, Orzeł Biały. Herb państwa polskiego, Warszawa 2003, s. 178-188.

${ }^{66}$ APP, Akta miasta Poznania I 2162, s. 171 - pieczęć typu III (fot. 11, 14); I 506, s. 120 pieczęć typu II (fot. 12, 15).

${ }^{67}$ P. S tr ó ż y k, Najstarszy herb Poznania, s. 283-284; t e n że, Systematyka, s. 140-141.

${ }^{68}$ Te n że, O potrzebie i możliwościach badań nad herbami złożonymi. Uwagi na przykładzie ikonograficznych źródeł heraldycznych z Wielkopolski, w: Ad fontes. O naturze źródła historycznego, Wrocław 2004, s. 201-225.

${ }^{69} \mathrm{~W}$ niniejszym artykule użyliśmy określeń: typ pieczęci i wariant pieczęci. Na konieczność przedyskutowania aparatu pojęciowego związanego z zagadnieniami typologii pieczęci 


\section{PIECZEĆ NACZELNIKA MIASTA POZNANIA Z OKRESU POWSTANIA STYCZNIOWEGO. ZAGADNIENIE AUTORSTWA ${ }^{70}$}

Wśród znanych i opublikowanych pieczęci z czasu powstania styczniowego odnotowana została $\mathrm{w}$ literaturze przedmiotu interesująca pieczęć używana przez naczelnika miasta Poznania (fot. 17) ${ }^{71}$. To sigillum o średnicy $32 \mathrm{~mm}$, znane z dokumentu przechowywanego w Bibliotece Kórnickiej PAN (fot. 16) 72 $^{72}$ wyobraża godło z herbu miasta Poznania. W polu pieczęci, oddzielonym linią ciągłą od otoku, ukazana została

zwrócił ostatnio uwagę Z. P i e ch, Uwagi o typologii i nazewnictwie pieczęci w polskich i zagranicznych badaniach sfragistycznych, w: Dawne pieczęcie. Typologia - metody badań interpretacje, Warszawa 2015, s. 37-39, który zaproponował posługiwanie się następującymi hierarchicznymi pojęciami: gatunek - typ - odmiana - egzemplarz. Zauważmy tu, że między typem pieczęci, czyli pojęciem określającym użytkowane pieczęcie konkretnego właściciela, a odmianą pieczęci, czyli pojęciem odnoszącym się do odcisków wykonanych za pomocą kilku różniących się szczegółami typariuszy tego samego typu pieczęci, jest jeszcze - jak sądzę miejsce na pojęcie wariantu pieczęci. $Z$ wariantem mielibyśmy do czynienia $\mathrm{w}$ przypadku użycia tego samego typariusza, a) poddanego drobnym przeróbkom, o ile nie kreowały one nowego właściciela typariusza (jak mogłoby się zdarzyć np. na pieczęci opata klasztoru przez przerytowanie imienia opata), lub też b) typariusza z ruchomym elementem, np. datownikiem, jak choćby w pieczęciach pocztowych. Nie określimy przecież odcisku pieczęci pocztowej ze zmienioną datą jako odmiany danego typu pieczęci; nie wprowadzimy też setek czy tysięcy typów danej pieczęci tylko dlatego, że na odciskach widnieje inna data, wykonana ruchomym elementem typariusza. Takie właśnie przypadki można byłoby określić mianem wariantu. W omawianym powyżej przypadku za warianty tego samego typu pieczęci (III) uznaliśmy pieczęcie z Korybutem (wariant A) i z Janiną (wariant B, wykreowany poprzez przerobienie typariusza). Na pewno kwestie te wymagają szerszego przedyskutowania i wykraczają poza możliwości niniejszego artykułu.

70 Tekst poniższy ukazał się już drukiem, ale - nie z winy autora - w mocno okaleczonej formie (ponieważ pozbawiony całkowicie przypisów i z pomylonymi fot.): Pomerania et alia. Opuscula Joachimo Zdrenka dedicata, red. J. Karczewska, M. Tureczek, Toruń 2017, s. $275-$ 280; zob. w tej kwestii J. K a r c z e w s k a, M. T u r e c z e k, List w sprawie tomu Pomerania et alia. Opuscula Joachimo Zdrenka dedicata, Kwartalnik Historyczny 124, 2017, nr 2, s. 401. Ponieważ wbrew zapowiedziom nie wydrukowano prawidłowej wersji tekstu w Studiach Zachodnich (t. 20), pozwalamy sobie ogłosić pełny tekst w tym miejscu.

71 Zob. J. I. S zt a k elb erg, Pieczęcie powstańcze 1863-1864, tłum. W. Śliwowska, przedm. S. Kieniewicz, tablice pieczęci i ilustracje przygotował S. K. Kuczyński, Warszawa 1988, s. 159, tabl. XXVI, ryc. 2. Ponieważ reprodukowana pieczęć znana jest z pojedynczego odcisku, ten zaś nie jest tak wyraźny, jak zamieszczona reprodukcja, sądzić należy, że podobizna została wyretuszowana na potrzeby wydawnicze. O stosowaniu takich zabiegów Wydawnictwo uprzedziło we wstępie do katalogu pieczęci, s. 189: „Z uwagi na zły stan zachowania odcisków niektórych pieczęci, które reprodukowane w druku straciłyby jeszcze na wyrazistości, Wydawnictwo zdecydowało się poddać je nieznacznym retuszom uczytelniającym napisy i rysunek w polu pieczęci. Retusze dokonane zostały z możliwie największą wiernością oryginałom".

72 Biblioteka Kórnicka PAN, rkps 7413, k. 24. Dokument papierowy o wymiarach $142 \times$ 65 mm, spisany atramentem, o następującej treści: „Główny Komisarz Policyi miasta Poznania - mianuje | niniejszym Obywatela Piotra Ryferta, członkiem straży bez|pieczeństwa - za okazaniem tego dowodu Obywatele miasta | winni Temuż uległe posłuszeństwo - | Porządek prawo. | Poznań dnia 3 Marca 1864 r. | N¹ Cyrkuł I |". Na wysokości pierwszej linii tekstu, na lewym marginesie litery: „w. z.”. 
brama miejska z trzema wieżami, z których środkowa, z pojedynczym otworem okiennym, jest wyższa od dwu zewnętrznych i zwieńczona blankami. Nad nią uwidoczniono ukoronowanego orła o rozpostartych skrzydłach, z głową skierowaną w prawą (heraldycznie) stronę. Na niższych wieżach umieszczono postacie świętych patronów miasta z zaznaczonymi wokół ich głów promienistymi aureolami. Święty Piotr, trzymający w prawicy klucz, stoi na wieży prawej, a św. Paweł, wsparty o miecz, na wieży lewej (heraldycznie). W otwartym prześwicie bramnym przedstawiono dwa skrzyżowane klucze o trójlistnych uchwytach, nad którymi uwidoczniono niewielki grecki krzyżyk. W dolnym półotoku pieczęci widnieje legenda wykonana regularną kapitałą o wyraźnie zaznaczonych szeryfach: NACZELN: MIASTA POZNAN. ${ }^{73}$. W górnym półotoku, wolnym od napisu, umieszczono dwie ośmiopromienne gwiazdki o pustym, okrągłym środku.

Pieczęć z wyobrażeniem godła z herbu miasta jest wyjątkowa pośród znanych pieczęci powstańczych, te bowiem przedstawiały zwykle w pierwszym okresie powstania dwupolowy herb z polskim Orłem i litewską Pogonią ${ }^{74}$, potem zaś trójpolowy herb z Orłem, Pogonią i ruskim Archaniołem Michałem ${ }^{75}$, wprowadzony dekretem z 10 V 1863 r., po przekształceniu się Komitetu Centralnego Narodowego w Rząd Narodowy. Znane są też powstańcze pieczęcie tylko z wizerunkiem Orła ${ }^{76}$, pieczęcie napisowe $^{77}$, pieczęcie z wizerunkami symbolicznymi (Matka Boska z Dzieciątkiem,

${ }^{73} \mathrm{~W}$ katalogu pieczęci i w indeksie legend i pieczęci zamieszczonych w pracy J. Sztakelberga, Pieczęcie, s. 332, 366, oddano inskrypcję napieczętną w formie: NACZELN: MIASTA POZNAŃ. Tymczasem ostatnią literą napisu jest z pewnością litera $N$, nie zaś $N$, po której umieszczona została kropka. W zależności od tego, czy uznamy ową kropkę za znak brachygraficzny, czy za znak interpunkcyjny, możemy odczytać inskrypcję - uwzględniając także znak skrótu w postaci dwukropka kończącego pierwsze słowo - jako: NACZELN(IK) MIASTA POZNAN(IA) lub też NACZELN(IK) MIASTA POZNAN[IA]. Ten drugi wariant, o czym poniżej, wydaje się bardziej uzasadniony.

${ }^{74}$ Orzeł i Pogoń ukazywane były na tych pieczęciach z pominięciem tarczy, umieszczane w tarczy zwieńczonej koroną, w tarczy bez korony, a niekiedy na dwu osobnych tarczach, zob. J. I. S z t a k e 1 b e r g, Pieczęcie, s. 22-25, 219-260, 327, tabl. VII-X, XXIV. Odnotujmy tu, że z przywołanej grupy pieczęci powstańczych wyłączyć należy pieczęć reprodukowaną na tabl. VIII, ryc. 7,2, pochodzącą z czasów Wiosny Ludów, zob. T. J e z i o r o w s k i, Herb Rzeczypospolitej z 1848 roku, w: Orzeł Biały (jak w przyp. 65), s. 261. Należy też pamiętać, że monografia Sztakelberga nie uwzględnia wszystkich typów powstańczych pieczęci, zob. przykładowo: Orzeł Biały - 700 lat herbu państwa polskiego [katalog wystawy], Warszawa 1995, s. 334-335, kat. VIII 71; J. D r eś c i k, Pieczęcie powstańcze 1863-1864 w zbiorach Muzeum Narodowego w Krakowie, Studia Historyczne 38, 1995, z. 2, s. 203-223.

75 Zwykle przedstawiano Orła, Pogoń i Archanioła w trójdzielnej tarczy zwieńczonej koroną, chociaż zdarzały się także pieczęcie z tarczami pozbawionymi korony oraz pieczęcie przedstawiające wymienione godła na trzech osobnych tarczach, zob. J. I. S z t a k e l b e r g, Pieczęcie, s. 25-35, 260-326, 328-331, tabl. XI-XXIII, XXV. Zagadnienie heraldyki powstańczej omówił S. K. K u c z y ńs ki, Orzeł Biały w powstaniach narodowych i ruchach wyzwoleńczych XIX wieku, w: Orzeł Biały (jak w przyp. 65), s. 252-255, a ostatnio T. J e z i o r o w s k i, Trzy kolory - czerwony, niebieski, biały. Trójpolowy herb Rzeczypospolitej na biżuterii narodowej, KMP 2013, nr 1 (1863), s. 256-276. Zob. także Orzeł Biały - 700 lat herbu, s. 335, kat. VIII, 72 oraz VIII, 74.

76 J. I. S z t a k e 1 b e r g, Pieczęcie, s. 21-22, 214-219, tabl. VI.

77 Tamże, s. 191-214, tabl. II-V. 
Krzyż, Oko Opatrzności, ręce splecione w uścisku) ${ }^{78}$ oraz nieliczne pieczęcie z innymi znakami heraldycznymi - dawnymi herbami ziemskimi (Podola, województwa sandomierskiego $)^{79}$ lub herbami szlacheckimi ${ }^{80}$.

Ikonograficzna wyjątkowość powstańczej pieczęci z poznańskim godłem herbowym w ogóle nie zainteresowała dotąd badaczy. W monumentalnym opracowaniu Jurija I. Sztakelberga poświęcono jej ledwie kilka słów, wskazując, że data wystawienia dokumentu (3 III 1864) i jego numer kancelaryjny ( $\left.\mathrm{N}^{\circ} 1\right)$ określają, kiedy owo sigillum zostało wykonane i wprowadzone do użycia. Widniejącą na dokumencie datę uznać należy za terminus ante quem sporządzenia matrycy pieczęci. W opracowaniu nie wskazano autora typariusza, chociaż twórcom powstańczych pieczęci poświęcono tam stosowną uwagę. Wiemy, że w zaborze pruskim pieczęcie powstańcze wykonywał Fryderyk Wilhelm Below, uznany pieczętarz i medalier, wykonawca szeregu pieczęci kościelnych z obszaru Wielkopolski ${ }^{81}$. W czerwcu 1863 r. Below był podejrzewany przez władze pruskie o wykonanie pieczęci dla działającego w Poznaniu Komitetu ${ }^{82}$. Na przełomie 1863 i 1864 r. pełnił obowiązki intendenta Organizacji Narodowej. Pod zarzutem udziału w ,polskim spisku” został aresztowany 22 VII 1864 r., jednakże z braku dowodów winy sąd zwolnił go 28 IV $1865 \mathrm{r}^{83} \mathrm{Na}$ podstawie analizy porównawczej Sztakelberg przypisał mu autorstwo dziewięciu znanych sobie odcisków pieczęci powstańczych Organizacji Narodowej w zaborze pruskim ${ }^{84}$. Autor ten zwrócił uwagę na istnienie podobieństw ikonograficznych pomiędzy pieczęciami, chociaż - poza wskazaniem na powtarzający się kształt tarczy herbowej i kształt wieńczącej ją korony - nie dokonał ich bliższej charakterystyki. We wspomnianej grupie znalazły się pieczęcie z następującymi inskrypcjami: DRUKARNIA NAROD(OWA) WOJ(EWÓDZTWA) AUGUSTOWSKIEGO ${ }^{85}$; KOMISARZ WOJEW(ÓDZTWA) POMORSKIEGO. ${ }^{86}$; NACZELNIK AGENTURY PRUS WSCHODNICH. ${ }^{87}$;

78 Tamże, s. 36-39, 333-337, tabl. XXVII.

79 Tamże, s. 35-36, 332, tabl. XXVI, ryc. 1 i 3; zob. także S. K. K u c z y ń s k i, Polskie herby ziemskie. Geneza, treści, funkcje, Warszawa 1993, s. 253.

${ }^{80}$ J. I. S z ta ke lb e rg, Pieczęcie, s. 36, 333, tabl. XXVI, ryc. 4.

${ }^{81}$ Sylwetkę i twórczość poznańskiego artysty opracował E. Majk ow ski, Fryderyk Wilhelm Below, pieczętarz i medalier poznański, patriota polski, 1822-1895, KMP 14, 1936, nr 3, s. 263-348 i odbitka (Biblioteka KMP 6); zob. także Z. G r o t, Fryderyk Wilhelm Below, wybitny medalier wielkopolski i patriota, Złotnik i Zegarmistrz 1936, s. 154-155; A. W i ę c e k, Dzieje sztuki medalierskiej w Polsce, wyd. 2, Kraków 1989, s. 154-155.

${ }^{82}$ E. M a j k o w s ki, Fryderyk Wilhelm Below, s. 276 (odbitka s. 16), uznał tę pieczęć za jedną z pierwszych wykonanych przez poznańskiego artystę dla władz powstańczych; J. I. S zta k elberg, Pieczęcie, s. 75.

${ }^{83}$ E. M a j k ow s k i, Fryderyk Wilhelm Below, s. 276-283 (odbitka s. 16-23); J. I. S z t a ke 1 b e rg, Pieczęcie, s. 75.

${ }^{84}$ J. I. S zta k e lb e rg, Pieczęcie, s. 71, 74-75, 316-319, tabl. XXI (zreprodukowano tam podobizny pięciu $\mathrm{z}$ dziewięciu wymienionych pieczęci).

${ }_{85}$ Tamże, s. 111, 316.

${ }^{86}$ Tamże, s. 158, 317. Autor zasugerował, że znane jedynie ze wzmianek pieczęcie komisarzy rządowych województw średzkiego i chełmińskiego, używane w kwietniu 1864 r., mogły być tego samego typu, co pieczęć komisarza województwa pomorskiego. Nie można zatem wykluczyć, że i te pieczęcie mogły wyjść spod ręki Fryderyka Wilhelma Belowa.

${ }^{87}$ Tamże, s. 158, 317, tabl. XXI, ryc. 1,3; „Znak i karabin do ręki bierzem”. Powstanie styczniowe i Rząd Narodowy 1863-1864. Katalog wystawy, Wrocław 2014, s. 92, nr 86. 
NACZELNIK POWIATU KONINSKIEGO ${ }^{88}$; NACZELNIK POWIATU WIELUNSKIEGO. ${ }^{89}$; ORGANIZATOR WOJSK(OWY) WOJ(EWÓDZTWA) ŚREDZKIEGO I. POZNANSKIEGO ${ }^{90}$; ORGANIZATOR W(OJSKOWY) | W(OJEWÓDZTWA) SREDZKIEGO. ${ }^{91}$; AGENTURA | W WROCŁAWIU.92; WYDZIAŁ WYKONAWCZY | W ZABORZE PRUSKIM. ${ }^{93}$. Charakterystyczny kształt korony wieńczącej tarcze herbowe wyobrażone na pieczęciach wykonanych w Poznaniu przez F. W. Belowa skłonił też J. I. Sztakelberga do przypisania mu autorstwa jeszcze jednej pieczęci powstańczej - z wizerunkiem Orła w tarczy i napisem w otoku: KOMISARZ RZĄDU NARODOWEGO | DLA | WIELKOPOLSKI ${ }^{94}$.

Wraz z kilkoma hipotetycznie wskazanymi pieczęciami, znanymi tylko ze wzmianek, daje to grupę kilkunastu pieczęci powstańczych, których autorem mógł być F. W. Below. Do tej grupy można - jak sądzę - dodać też pieczęć naczelnika miasta Poznania. Podstawą takiego twierdzenia jest analiza ikonograficzna pewnych jej elementów. Przede wszystkim wskazuje na to kształt orła widniejącego nad środkową wieżą bramy miejskiej (fot. 19). Porównując go z orłem na trójpolowej tarczy z herbem Rzeczypospolitej, umieszczonej na pieczęci komisarza województwa pomorskiego (fot. 20), przypisywanej F. W. Belowowi ${ }^{95}$, dostrzegamy zbieżności, które nie mogą być przypadkowe. Kształt orlich skrzydeł, łap i ogona, rysunek poszczególnych piór i głowa zwieńczona koroną otwartą zdradzają, że wizerunki te wyszły spod tej samej ręki. Nawet gdybyśmy uznali, że podobieństwo rysunku wynikać może tylko z zastosowania jakiegoś wspólnego wzorca, to konspiracyjny kontekst wytwarzania powstańczych typariuszy zdaje się czynić taką możliwość mniej prawdopodobną. Poza tym kształt liter zastosowanych w otoku pieczęci naczelnika miasta Poznania jest analogiczny do kształtu liter na pieczęciach uznanych za dzieło F. W. Belowa (fot. 22). Dzięki pieczęciom należącym do naczelnika powiatu wieluńskiego (fot. 21) i do naczelnika agentury Prus Wschodnich, w legendzie których znalazło się słowo NACZELNIK, możemy nawet porównać sposób wykonania tego samego słowa na

88 J. I. S z t a k e 1 b e rg, Pieczęcie, s. 131, 317.

89 Tamże, s. 131, 317, tabl. XXI, ryc. 2,2.

${ }^{90}$ Pieczęć przywołana przez E. M a j k ow s k i e g o, Fryderyk Wilhelm Below, s. 277 278 (odbitka s. 17-18), znana jest tylko z opisu; J. I. S z t a k e l b e r g, Pieczęcie, s. 159, 318.

${ }^{91}$ Fotografię tłoka ukrytego w spince mankietowej reprodukował S. G a w ę d a, Wybrane źródła dotyczące organizacji powstania w woj. średzkim w 1864 r., Studia i Materiały do Dziejów Wielkopolski i Pomorza 8, 1963, z. 2 (16), s. 111, ryc. 2; J. I. S z ta ke lb e rg, Pieczęcie, s. 158-159, 318, tabl. XXI, ryc. 3. Autor wskazał na możliwość wykonania przez Belowa jeszcze dwu innych pieczęci organizatorów wojskowych - „w tym samym czasie sporządzone zostały pieczęcie organizatorów województwa bydgoskiego i poznańskiego. Jest rzeczą wątpliwą, czy były innego rodzaju i czy wykonywał je inny pieczętarz” (s. 159).

92 J. I. S z t a k e 1 b e r g, Pieczęcie, s. 176, 318, tabl. XXI, ryc. 4.

${ }_{93}$ Tamże, s. 156, 318-319, tabl. XXI, ryc. 5.

${ }^{94}$ Tamże, s. 155-156, 218, tabl. VI, ryc. 9. Pieczęć znana jest $\mathrm{z}$ dokumentu wystawionego 22 IX 1863 r. Analogicznej pieczęci prawdopodobnie używał także Komitet Wielkopolski. Obydwa sigilla - jak zasugerował Sztakelberg - mogły powstać w maju 1863 r. Zob. także J. Dr és c i k, Pieczęcie, s. 213.

${ }^{95}$ Podobizna tej pieczęci nie została opublikowana przez J. I. S z t a k e 1 b e r g a, Pieczęcie, tabl. XXI. Trzy jej odciski znajdują się na dokumentach powstańczych przechowywanych przez Bibliotekę Kórnicką PAN, rkps 7400, k. 70-72. 
różnych pieczęciach (fot. 21-22) ${ }^{96}$. Poza tym na pieczęci poznańskiej - wzorem innych atrybuowanych Belowowi - legenda kończy się kropką, postawioną na linii podstawy napisu ${ }^{97}$, a skrót przybiera postać dwukropka, w którym dolna kropka postawiona jest na linii podstawy napisu, górna zaś nieco ponad połową jego wysokości ${ }^{98}$. Jest jeszcze jeden charakterystyczny element, na który należy zwrócić uwage - to dwie ośmiopromienne gwiazdki o pustym, okrągłym środku. Takie same gwiazdki (także po dwie) znajdują się na dwu wymienionych już przez nas pieczęciach, opatrzonych napisami: AGENTURA | W WROCŁAWIU. oraz WYDZIAŁ WYKONAWCZY | W ZABORZE PRUSKIM. ${ }^{99}$. Wszystkie wskazane podobieństwa pozwalają - jak sądzę - dopisać do zespołu pieczęci atrybuowanych F. W. Belowowi także tę, przeznaczoną dla naczelnika miasta Poznania.

Zauważmy na koniec, że nie wszystkie pieczęcie powstańcze z obszaru zaboru pruskiego łączone są z osobą F. W. Belowa i jego poznańską aktywnością. J. I. Sztakelberg wskazał na osiemnaście pieczęci, „najwidoczniej rytych przez pieczętarza, który nie znał wizerunku polskiego orła, dlatego też orzeł w herbie wyryty został z opuszczonymi skrzydłami (typu niemieckiego)”, uznając na tej podstawie, że „pieczęcie te wykonano w Prusach" ${ }^{100}$. W innym miejscu wskazał też na zespół sześciu pieczęci, które z powodu „wyraźnego podobieństwa kształtu i rysunku” prawdopodobnie pochodziły ze wspólnego źródła, a wykonane zostały „w tym samym miejscu i w tym samym czasie (pierwsza połowa 1864 r.)". Uznał przy tym, że pieczęcie wykonano w Poznaniu ${ }^{101}$. Kwestia autorstwa wielu pieczęci powstańczych z zaboru pruskiego wymagać będzie zatem dalszych studiów i krytycznego zweryfikowania hipotez zgłoszonych w literaturze przedmiotu.

${ }_{96}$ J. I. S zta k e 1 b e rg, Pieczęcie, tabl. XXI, ryc. 1,3 oraz ryc. 2,2.

${ }^{97}$ Końcową kropkę widzimy na wszystkich pięciu reprodukowanych w monografii pieczęciach, przypisanych F. W. Belowowi, zob. J. I. S ztakelberg, Pieczęcie, tabl. XXI. Zwróćmy tu uwagę, że w zakresie występowania końcowej kropki opisy dołączone do tablicy nie są miarodajne. Końcowa kropka w legendzie jest też na pieczęci komisarza województwa pomorskiego - reprodukowanej w niniejszym artykule (fot. 18), a u Sztakelberga jedynie opisanej. Mając na uwadze wszystkie te pieczęcie przypisywane F. W. Belowowi, których inskrypcja zakończona jest kropką, uznaję, że także kropka w legendzie pieczęci naczelnika miasta Poznania ma charakter znaku interpunkcyjnego, nie zaś brachygraficznego. Zważywszy także i to, że słowo NACZELN(IK) zostało skrócone przy użyciu innego znaku - dwukropka, wydanie napisu na tej pieczęci powinno przybrać następującą postać: NACZELN(IK) MIASTA POZNAN[IA].

98 Taki znak brachygraficzny widnieje na pewno na pieczęci z legendą: KOMISARZ WOJEW(ÓDZTWA) POMORSKIEGO. (fot. 18), a - sądząc z opisu zamieszczonego w monografii J. I. S z t a k e l b e r g a, s. 316 (nr XXI, 1) - także na pieczęci z napisem: DRUKARNIA NAROD(OWA) WOJ(EWÓDZTWA) AUGUSTOWSKIEGO.

99 Tamże, tabl. XXI, ryc. 4 i 5.

100 Tamże, s. 71, 157, 319-324, tabl. XXII.

101 J. I. S z t a k e lbe rg, Oznaczenia pieczęci w wydawnictwie „Dokumenty Komitetu Centralnego Narodowego i Rządu Narodowego (1862-1864)", Przegląd Historyczny 60, 1969, s. 574; t e nż e, Pieczęcie, s. 159 (uściślenie czasu wykonania na marzec-kwiecień 1864 r.), 314-316 (nr XX 7,1, 7,2, 7,3, 7,4, 7,5, 8), tabl. XX, ryc. 7,5, 8; Dokumenty Komitetu Centralnego i Rządu Narodowego 1862-1864 / Документы Центрального Национального Комитета и Национального Правительства 1862-1864, Wrocław-Warszawa 1968, il. 14, 16 (po s. LXXVIII). 


\section{BIBLIOGRAFIA}

Adamczewski M., Funkcje użytkowe herbu miejskiego do końca XVIII wieku, Rocznik Polskiego Towarzystwa Heraldycznego, seria nowa 4, 1999.

Adamczewski M., Heraldyka miast wielkopolskich do końca XVIII wieku, Warszawa 2000.

Bogucka M., Samsonowicz H., Dzieje miast i mieszczaństwa w Polsce przedrozbiorowej, Wrocław 1986.

Borkowska M. OSB, Leksykon zakonnic polskich epoki przedrozbiorowej, t. I, Warszawa 2004.

Dembiński P., Fundacja i erekcja kolegiaty św. Marii Magdaleny w Poznaniu, Kronika Miasta Poznania 2003, nr 3 (Stara i nowa fara).

Dreścik J., Pieczęcie powstańcze 1863-1864 w zbiorach Muzeum Narodowego w Krakowie, Studia Historyczne 38, 1995, z. 2.

Dubowski A., Zabytkowe kościoły Poznania, Poznań 1952.

Gawęda S., Wybrane źródła dotyczące organizacji powstania w woj. średzkim w 1864 r., Studia i Materiały do Dziejów Wielkopolski i Pomorza 8, 1963, z. 2 (16).

Grot Z., Fryderyk Wilhelm Below, wybitny medalier wielkopolski i patriota, Złotnik i Zegarmistrz 1936.

Grycz M., Grodzicki Jan, w: Wielkopolski słownik biograficzny, Warszawa-Poznań 1981.

Gumowski M., Handbuch der polnischen Siegelkunde, Graz 1966.

Gumowski M., Pieczęcie i herby miast wielkopolskich, Poznań 1932.

Haisig M., Pieczęć i herb miasta Poznania, w: Dziesięć wieków Poznania, t. I, Poznań-Warszawa 1956.

Herb miasta Poznania. Publikacja z okazji wystawy zorganizowanej w Starym Ratuszu, opr. J. Olejniczak, Poznań 1967.

Hlebionek M., Katalog pieczęci przy dokumentach samoistnych w zasobie Archiwum Państwowego w Bydgoszczy, Warszawa 2012.

Jaworska A., Orzeł Biały. Herb państwa polskiego, Warszawa 2003.

Jeziorowski T., Herb Rzeczypospolitej z 1848 roku, w: Orzeł Biały - herb państwa polskiego, Warszawa 1996.

Jeziorowski T., Trzy kolory - czerwony, niebieski, biały. Trójpolowy herb Rzeczypospolitej na biżuterii narodowej, Kronika Miasta Poznania 2013, nr 1 (1863).

Jurek T., Przebieg lokacji Poznania, w: Civitas Posnaniensis. Studia z dziejów średniowiecznego Poznania, Poznań 2005.

Jurek T., Wokół zagadek najdawniejszych dziejów poznańskiej fary, Kronika Miasta Poznania 2003, nr 3 (Stara i nowa fara).

Katalog zabytków sztuki w Polsce, seria nowa, t. VII, cz. II/2, pod red. Z. Kurzawy, A. Kusztelskiego, Warszawa 2002.

Kolak W., Marecki J., Leksykon godeł zakonnych, Łódź 1994.

Kowalski J., Gotyk wielkopolski. Architektura sakralna XIII-XVI wieku, Poznań 2010.

Kruk M. P., Święta Katarzyna Aleksandryjska i inni święci wschodni w kulcie i sztuce europejskiej u schyłku średniowiecza i na progu czasów nowożytnych, w: Mistrz i Katarzyna. Hans von Kulmbach i jego dzieła dla Krakowa / Der Meister und Katharina. Hans von Kulmbach und seine Werke für Krakau, Kraków 2018.

Kuczyński S. K., Orzeł Biały w powstaniach narodowych i ruchach wyzwoleńczych XIX wieku, w: Orzeł Biały - herb państwa polskiego, Warszawa 1996.

Kuczyński S. K., Polskie herby ziemskie. Geneza, treści, funkcje, Warszawa 1993.

Kurzawa Z., Kusztelski A., Historyczne kościoły Poznania. Przewodnik, Poznań 2006.

Łukaszewicz J., Obraz historyczno-statystyczny miasta Poznania w dawniejszych czasach, t. I-III, Poznań 1838.

Majkowski E., Fryderyk Wilhelm Below, pieczętarz i medalier poznański, patriota polski, 1822-1895, Kronika Miasta Poznania 14, 1936, nr 3 i odbitka (Biblioteka Kronika Miasta Poznania 6). 
Mrozowski P., O sztuce i stylizacji heraldycznej w Polsce XIV i XV wieku, Rocznik Polskiego Towarzystwa Heraldycznego, seria nowa, 1, 1993.

Nowacki J., Dzieje archidiecezji poznańskiej, t. II, Poznań 1964.

Nożyński T., Złotnictwo poznańskie do końca XVIII w., Studia i Materiały do Dziejów Wielkopolski i Pomorza 6, 1960, z. 1 (11).

Orzeł Biały - 700 lat herbu państwa polskiego [katalog wystawy], Warszawa 1995.

Piech Z., Uwagi o typologii i nazewnictwie pieczęci w polskich i zagranicznych badaniach sfragistycznych, w: Dawne pieczęcie. Typologia - metody badań - interpretacje, Warszawa 2015.

Pokora P., Herby na pieczęciach episkopatu doby jagiellońskiej (do końca XV wieku), w: Pieczęcie herbowe - herby na pieczęciach, Warszawa 2011.

Prausmüller T., Św. Katarzyna, klasztor dominikanek w Poznaniu 1283-1822, Poznań 1928.

Radtke I., Kancelaria miasta Poznania do roku 1570, Warszawa 1967.

Radtke I., Kancelaria miasta Poznania w latach 1570-1793, w: Historia prawa, historia kultury. Liber memorialis Vitoldo Maisel dedicatus, Poznań 1994.

Skibiński S., Gotycka architektura kościoła farnego pod wezwaniem Marii Magdaleny w Poznaniu, w: Początki i rozwój Starego Miasta w Poznaniu w świetle badań archeologicznych i urbanistyczno-architektonicznych, Warszawa-Poznań 1977.

Skorupińska A., Klasztory żeńskie w średniowiecznej diecezji poznańskiej, w: Historia życia konsekrowanego w archidiecezji poznańskiej, Poznań 2010.

Spis złotników poznańskich od XV do XVIII wieku wg Tadeusza Nożyńskiego. Materiały do dziejów złotnictwa poznańskiego, opr. Z. Dolczewski, Kronika Miasta Poznania 2000, nr 1 (Złotnicy).

Stefaniak P., Najstarszy polski klasztor dominikanek klauzurowych i jego mieszkanki, Kronika Miasta Poznania 2004, nr 3 (Nasi dominikanie).

Stróżyk P., Superekslibrisy herbowe z poznańskich ksiąg miejskich. Materiały do historii herbu Poznania, Poznański Rocznik Archiwalno-Historyczny 12-14, 2005-2007.

Stróżyk P., Zapomniany wiersz na herb Poznania z XVIII wieku, Roczniki Historyczne 76, 2010.

Stróżyk P., Najstarszy herb Poznania, w: Civitas Posnaniensis. Studia z dziejów średniowiecznego Poznania, Poznań 2005.

Stróżyk P., O potrzebie i możliwościach badań nad herbami złożonymi. Uwagi na przykładzie ikonograficznych źródeł heraldycznych z Wielkopolski, w: Ad fontes. O naturze źródła historycznego, Wrocław 2004.

Stróżyk P., Okoliczności wprowadzenia wizerunku murów miejskich do herbu Poznania, w: Mundus hominis - cywilizacja, kultura, natura. Wokół interdyscyplinarności badań historycznych, Wrocław 2006 (Acta Universitatis Wratislaviensis, Historia CLXXV).

Stróżyk P., Systematyka średniowiecznych i nowożytnych pieczęci miejskich Poznania. Status causae et controversiae, Roczniki Historyczne 72, 2006.

Sztakelberg J. I., Oznaczenia pieczęci w wydawnictwie „Dokumenty Komitetu Centralnego Narodowego i Rządu Narodowego (1862-1864)", Przegląd Historyczny 60, 1969.

Sztakelberg J. I., Pieczęcie powstańcze 1863-1864, thum. W. Śliwowska, przedm. S. Kieniewicz, tablice pieczęci i ilustracje przygotował S. K. Kuczyński, Warszawa 1988.

Św. Katarzyna. Klasztor dominikanek w Poznaniu 1283-1822. Salezjanie 1926-1928, Poznań 1928.

Trelińska B., Gotyckie pismo epigraficzne w Polsce, Lublin 1991.

Wasilkowska A., Budzyniewicz Wojciech, w: Wielkopolski słownik biograficzny, Warszawa-Poznań 1981.

Wasilkowska A., O złotnikach wyszkolonych w Krakowie, a działających w Poznaniu w XVII wieku, Kronika Miasta Poznania 2000, nr 1 (Złotnicy).

Wiesiołowski J., Dominikanie w miastach wielkopolskich w okresie średniowiecza, w: Studia nad historią dominikanów w Polsce 1222-1972, t. I, Warszawa 1975.

Wiesiołowski J., Dominikanki poznańskie w kręgu mecenatu Przedpełkowiców, Kronika Miasta Poznania 2004, nr 3 (Nasi dominikanie). 
Wiesiołowski J., Klasztory średniowiecznego Poznania, w: Początki i rozwój Starego Miasta w Poznaniu w świetle badań archeologicznych i urbanistyczno-architektonicznych, Warszawa-Poznań 1977.

Więcek A., Dzieje sztuki medalierskiej w Polsce, wyd. 2, Kraków 1989.

Wiszewski P., Herb mało użyteczny. O słabości tradycji heraldycznej wybranych klasztorów żeńskich na Śląsku (XIII - 1. połowa XIX w.), w: Polska heraldyka kościelna. Stan i perspektywy badań, Warszawa 2004.

Władze miasta Poznania, t. I, opr. J. Wiesiołowski, Z. Wojciechowska, Poznań 2003.

Zbiór tłoków i stempli pieczętnych w zasobie Archiwum Państwowego w Poznaniu, red. P. Pokora, Poznań 2015.

Znak i karabin do ręki bierzem. Powstanie styczniowe i Rząd Narodowy 1863-1864. Katalog wystawy, Wrocław 2014.

Znamierowski A., Elementy herbu polskiego 1295-1995, w: Orzeł Biały - herb państwa polskiego, Warszawa 1996.

\section{Studies on selected seals with the arms of the city of Poznań}

\section{Summary}

The three studies presented here deal with some questions related to seals displaying the coatof-arms of the city of Poznań. In the first one the medieval and early modern seals of Dominican Nuns of Poznań. On the four early modern types of their seal the nuns placed, besides the image of St. Catherine, a shield with crossed keys (the oldest arms of the city). Its integration with the seal may be connected to the integration of the nunnery with the town community at the turn of the $15^{\text {th }}$ and $16^{\text {th }}$ centuries. The second study describes two variants of a city seal (type III). In variant A, on the chest of the White Eagle there was the arms Korybut of King Michał, while in variant B it was the arms Janina of King Jan III. The seal of type III was introduced into use in 1671, It replaced the seal of type II. The third study argues that the author of another seal from the time of the January Uprising (1863-1864) was a $19^{\text {th }} \mathrm{c}$. artist and engraver from Poznań, Friedrich Wilhelm Below. Thus the number of seals attributed to him has increased. 

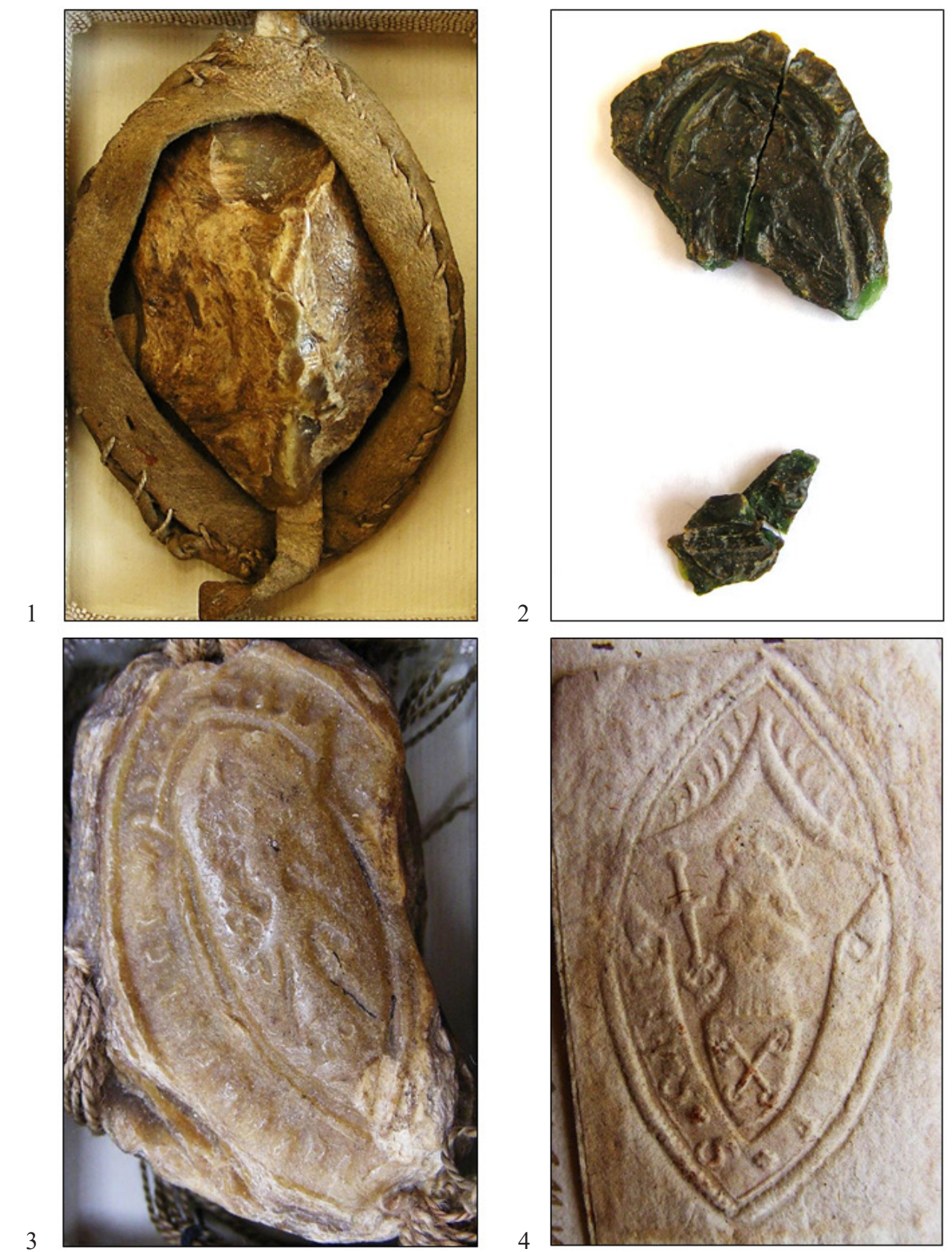

1. Pieczęć dominikanek poznańskich przy dokumencie z 1404 roku; woskowa miska (APP, Dominikanki Poznań, sygn.: D 5)

2. Pieczęć dominikanek poznańskich przy dokumencie z 1404 roku; trzy luźno zachowane, woskowe fragmenty odwarstwionego lica (APP, Dominikanki Poznań, sygn.: D 5)

3. Pieczęć woskowa dominikanek poznańskich przy dokumencie z 1412 roku (APP, Dominikanki Poznań, sygn.: D 6)

4. Pieczęć dominikanek poznańskich na dokumencie z 1649 roku (APP, Akta miasta Poznania, sygn.: I 418, k. 731) 
5
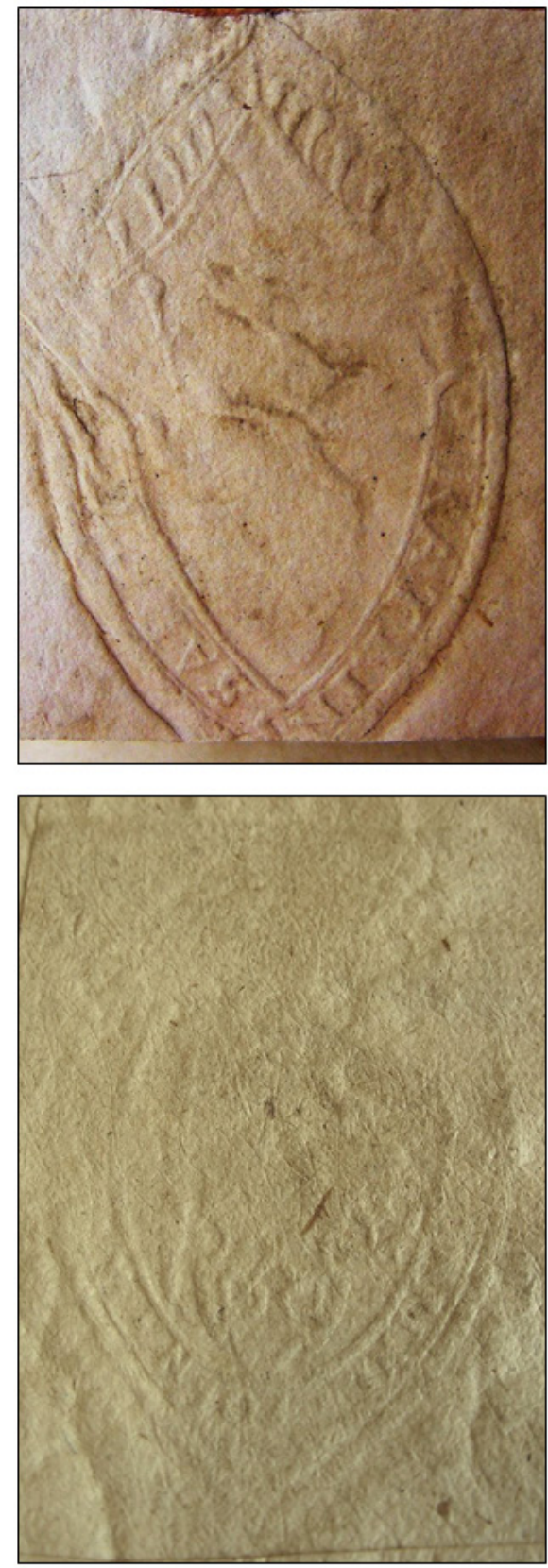

6

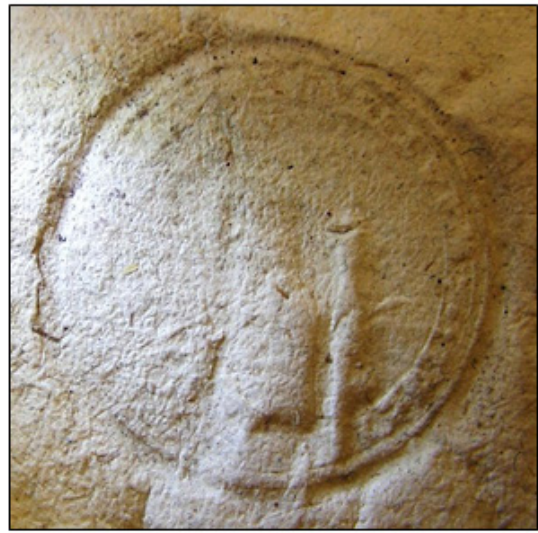

8

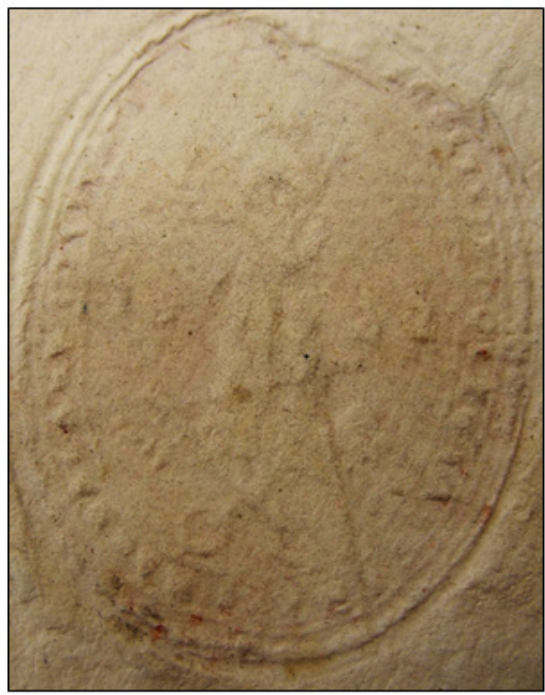

5. Pieczęć dominikanek poznańskich na dokumencie z 1747 roku (APP, Akta miasta Poznania, sygn.: I 1873, s. 457a)

6. Pieczęć dominikanek poznańskich na dokumencie z 1762 roku (APP, Dominikanki Poznań, sygn.: 48, s. 64)

7. Pieczęć dominikanek poznańskich na dokumencie z 1778 roku (APP, Dominikanki Poznań, sygn.: 39 , s. 1)

8. Pieczęć kościoła farnego św. Marii Magdaleny na dokumencie z 1798 roku (APP, Cechy miasta Poznania, sygn.: 449, k.42) 

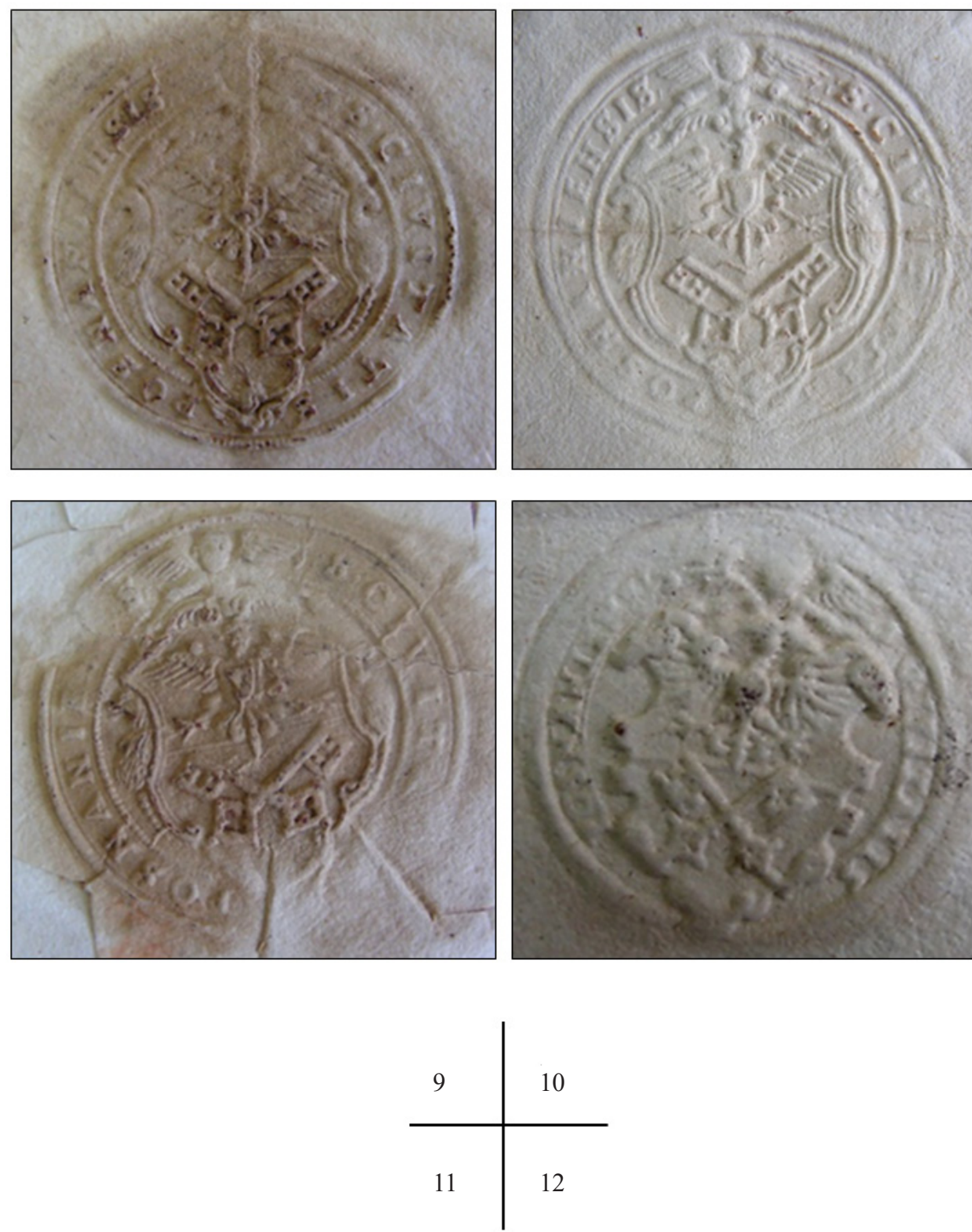

9. Pieczęć miasta Poznania na dokumencie z 1687 roku, typ III/A (APP, Akta miasta Poznania, sygn.: I 2115, s. 9)

10. Pieczęć miasta Poznania z sumariusza z lat 1714-1729, typ III/B (APP, Akta miasta Poznania, sygn.: I 1494, s. 37)

11. Pieczęć miasta Poznania na dokumencie z 1688 roku, typ III/B (APP, Akta miasta Poznania, sygn.: I 2162, s. 171)

12. Pieczęć miasta Poznania na dokumencie z 1578 roku, typ II (APP, Akta miasta Poznania, sygn.: I 506, s. 120) 

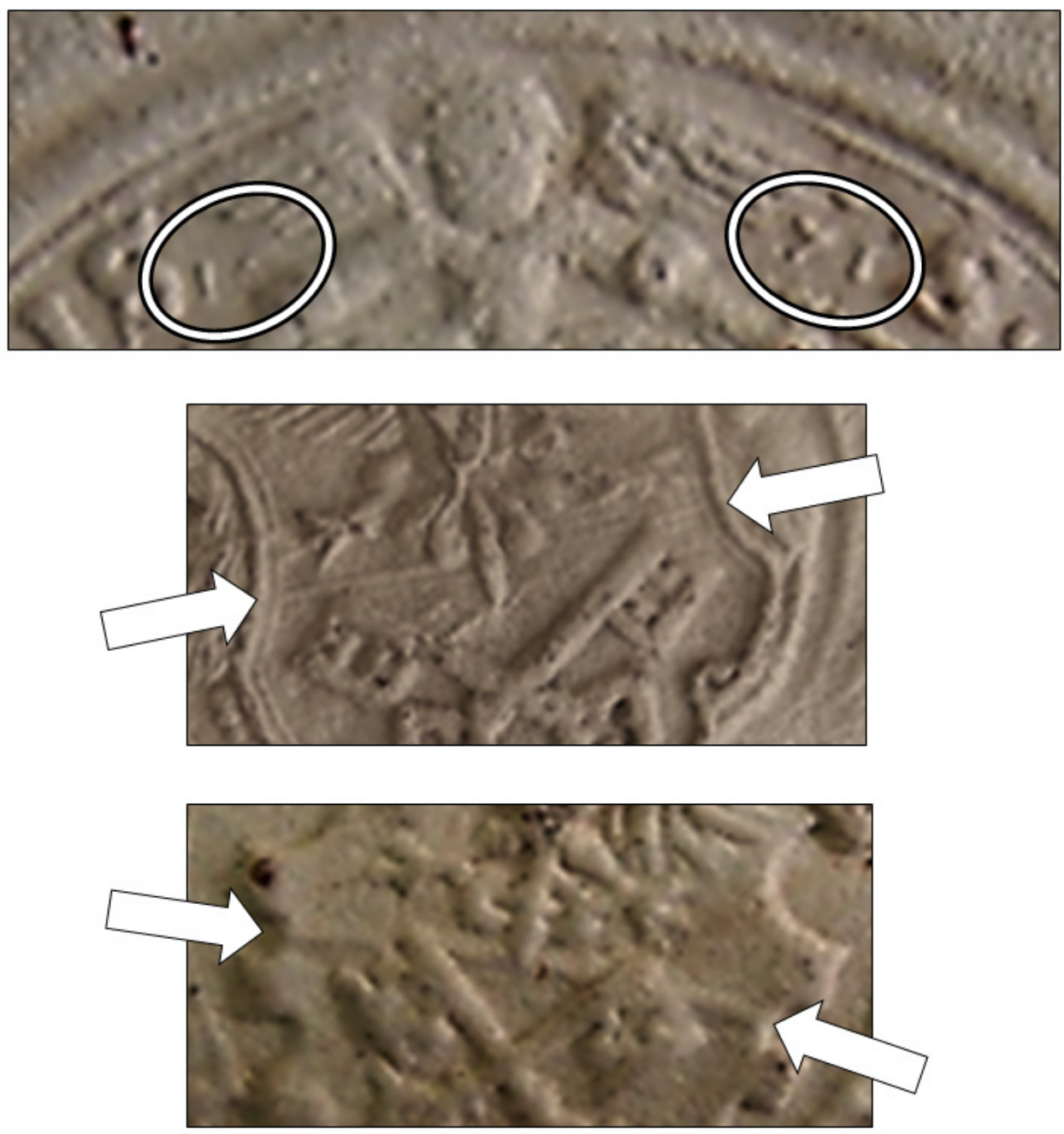

13

14

15

13. Pieczęć miasta Poznania - lata 1714-1729, typ III/B; fragment z widoczną datą: 16-71 (APP, Akta miasta Poznania, sygn.: I 1494, s. 37)

14. Pieczęć miasta Poznania - 1688 rok, typ III/B; fragment z widocznym podziałem pola tarczy (APP, Akta miasta Poznania, sygn.: I 2162, s. 171)

15. Pieczęć miasta Poznania - 1578 rok, typ II; fragment z widocznym podziałem pola tarczy (APP, Akta miasta Poznania, sygn.: I 506, s. 120) 


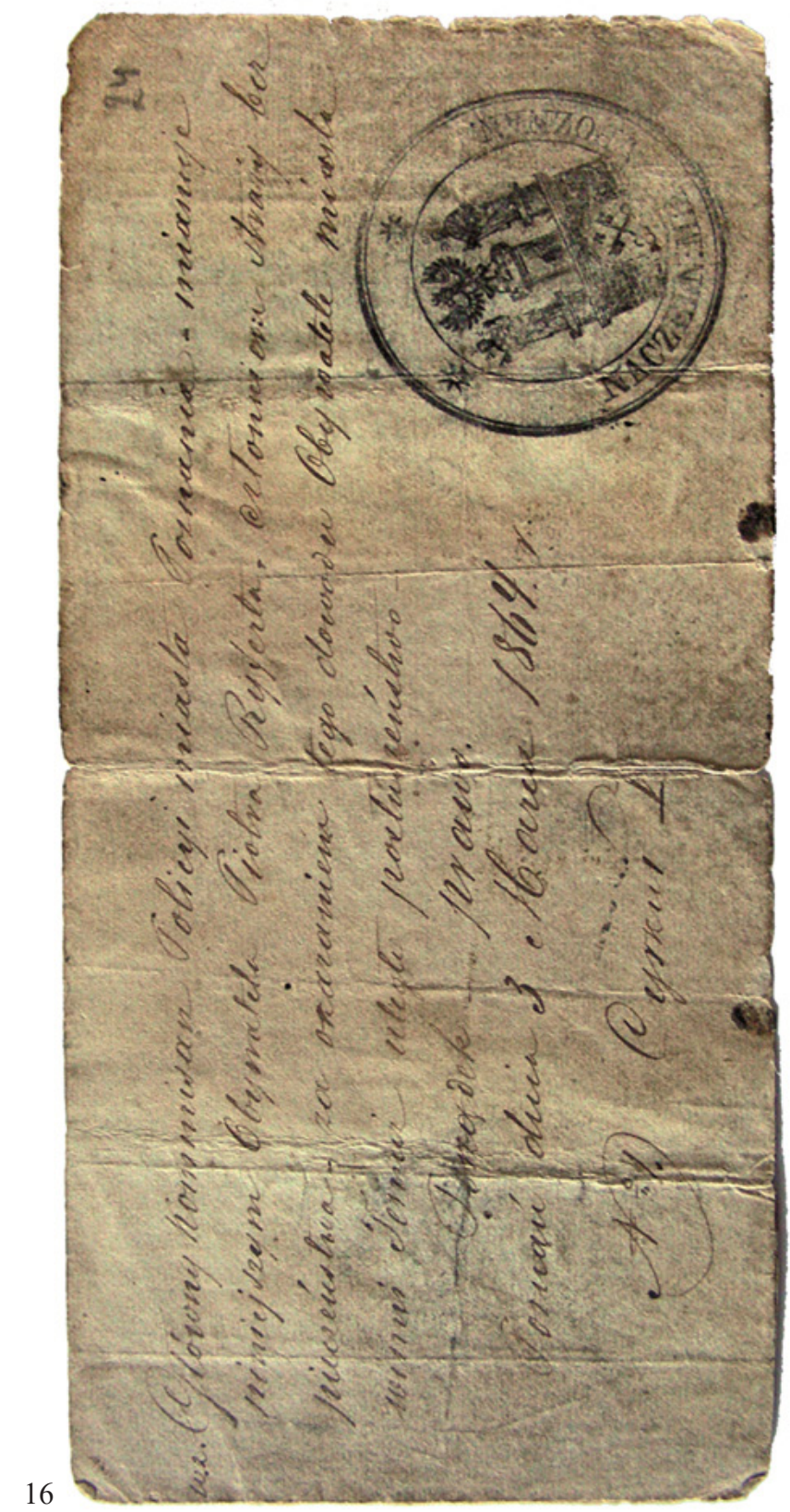

16. Dokument powstańczy z 1864 roku z pieczęcią naczelnika miasta Poznania (BK PAN, rkps 7413, k. 24) 

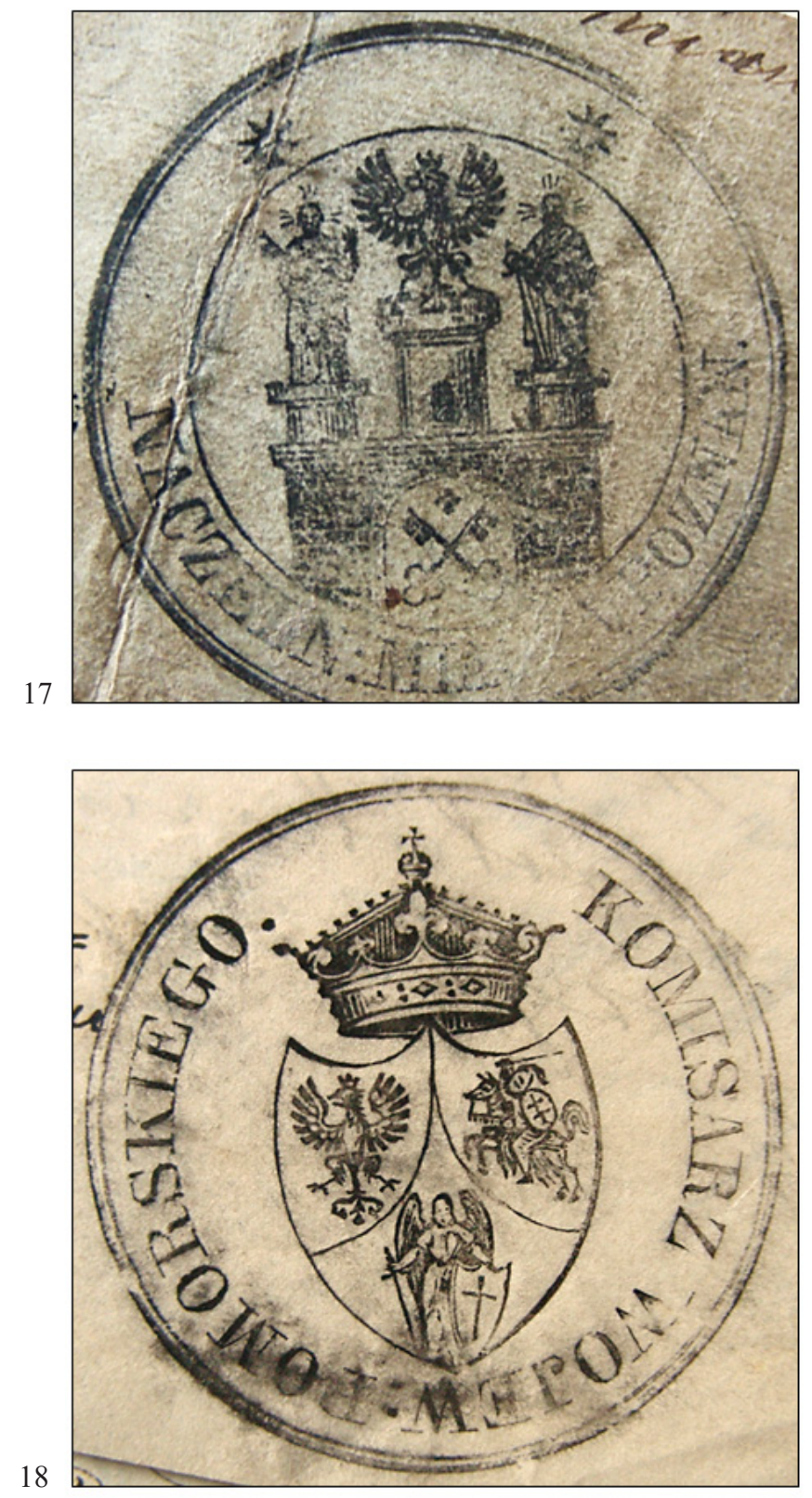

17. Pieczęć naczelnika miasta Poznania z 1864 roku (BK PAN, rkps 7413, k. 24)

18. Pieczęć komisarza województwa pomorskiego z [1864] roku (BK PAN, rkps 7400, k. 70) 

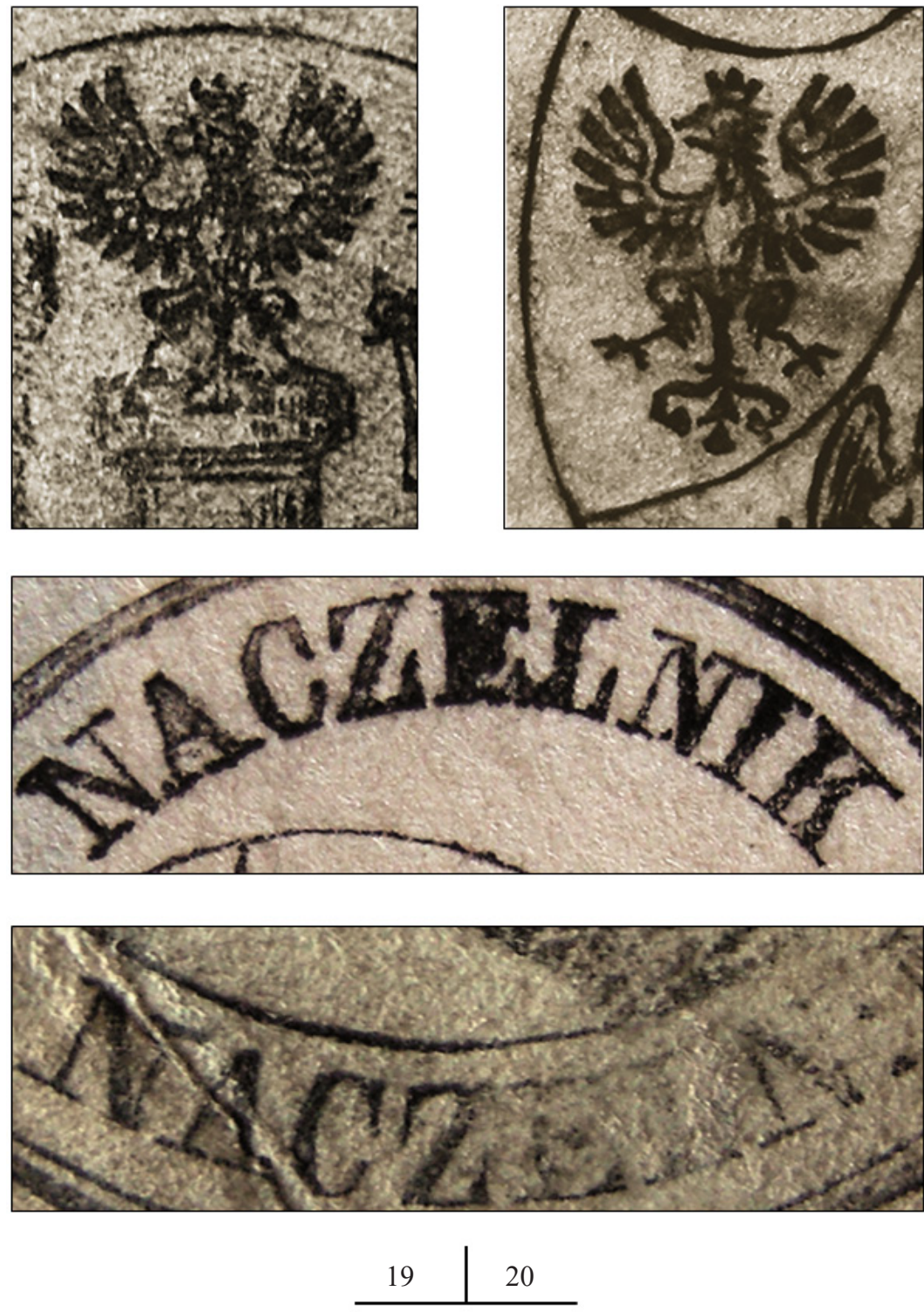

21

22

19. Pieczęć naczelnika miasta Poznania - 1864 rok; fragment z Orłem (BK PAN, rkps 7413, k. 24)

20. Pieczęć komisarza województwa pomorskiego - [1864] rok; fragment z Orłem (BK PAN, rkps 7400, k. 70)

21. Pieczęć naczelnika powiatu wieluńskiego - 1864 rok; fragment legendy napieczętnej (BK PAN, rkps. 7413, k. 28)

22. Pieczęć naczelnika miasta Poznania - 1864 rok; fragment legendy napieczętnej (BK PAN, rkps. 7413 , k. 24)

(Fot. 1-8 i 16-22: Paweł Stróżyk; fot. 9-15: Magdalena Kadziszewska-Stróżyk) 